Revista de Derecho Público: Teoría y Método

\title{
EL PRINCIPIO CONSTITUCIONAL DE ESTABILIDAD PRESUPUESTARIA EN EL MARCO DE LA MACROECONOMÍA: CONSECUENCIAS Y DIFICULTADES DE SU JURIDIFICACIÓN*
}

\section{THE CONSTITUTIONAL PRINCIPLE OF BUDGETARY STABILITY IN THE CONTEXT OF MACROECONOMICS: CONSEQUENCES AND DIFFICULTIES OF ITS JURIDIFICATION}

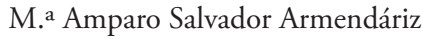 \\ Profesora Titular de Derecho Administrativo \\ Universidad de Navarra \\ Orcid: 0000-0001-7293-3932
}

\footnotetext{
* Este trabajo se terminó el 20 de julio de 2020.

Este trabajo tiene su origen en la ponencia presentada el 29 de noviembre de 2019, en el XIV Seminario de Teoría y Método, celebrado en Pamplona, en la Universidad de Navarra. El título y el objeto de la ponencia defendida entonces fue El principio constitucional de estabilidad presupuestaria y el derecho administrativo. La ponencia tenía dos partes bien diferenciadas. Este artículo desarrolla la primera de ellas, la relativa al origen, contenido y significado del propio art. $135 \mathrm{CE}$ como instrumento de la política económica, desde la perspectiva del Derecho público. Quiero aprovechar para agradecer a los participantes en aquella jornada todos sus comentarios. Especialmente a Antonio Fortes, a Jorge GarcíaAndrade y a José Luis García de Cal que formaron parte de la mesa en la que se presentó ese trabajo.

Quiero también agradecer a los revisores de este trabajo por sus comentarios y correcciones que me han ayudado a mejorar su resultado.

Abreviaturas: AGE: Administración General del Estado. AIReF: Autoridad Independiente de Responsabilidad Fiscal. ATC: Auto del Tribunal Constitucional. BCE: Banco Central Europeo. CCAA: Comunidades Autónomas. CE: Constitución Española. EELL: Entidades Locales. EEUU: Estados Unidos de América. FMI: Fondo Monetario Internacional. IPC: Índice de precios al consumo. LOEPSF: Ley Orgánica 2/2012, de Estabilidad Presupuestaria y Sostenibilidad Financiera. PIB: Producto Interior Bruto. RAP: Revista de Administración Pública. RDL: Real Decreto Ley. REDA: Revista Española de Derecho Administrativo. REDC: Revista Española de Derecho Constitucional. RGDA: Revista General de Derecho Administrativo. STC: Sentencia del Tribunal Constitucional. TECG: Tratado de Estabilidad, Coordinación y Gobernanza. TFUE: Tratado de Funcionamiento de la Unión Europea. TJUE: Tribunal de Justicia de la Unión Europea. TS: Tribunal Supremo
} 
RESUMEN: La reforma del art. 135 de la CE y la consiguiente incorporación del régimen de estabilidad presupuestaria han impactado en nuestro modelo de Constitución económica. Se ha reforzado el lenguaje macroeconómico presente en la CE: PIB, recesión económica, volumen de deuda pública, déficit público. Por otro lado, la constitucionalización del compromiso de estabilidad presupuestaria preexistente en el nivel europeo ha elevado la integración de Espańa con Europa al máximo nivel y afectado profundamente nuestra política fiscal. El alcance y la vinculatoriedad del nuevo mandato constitucional pueden contrastarse con ocasión de la crisis de la COVID-19. Ello permite analizar las consecuencias y dificultades que plantea su juridificación.

PALABRAS CLAVE: estabilidad presupuestaria; política fiscal; política monetaria; constitución económica; macroeconomía; sostenibilidad.

ABSTRACT: The amendment of Article 135 of the Spanish Constitution (CE) and the subsequent incorporation of the budgetary stability regime have impacted our existing economic Constitution model. The macroeconomic language present in the EC has been reinforced: GDP, economic recession, volume of public debt, public deficit. Additionally, the constitutionalisation in Spain of the pre-existing commitment to budgetary stability at the European level has reaised Spain's level of integration with Europe to the highest level and profoundly affected the fiscal policy. The scope and binding nature of the new constitutional mandate can be tested in light of the COVID-19 crisis. This makes it possible to analyse the consequences and difficulties wich may arise as a consequence of its juridificatio

KEYWORDS: budgetary stability; fiscal policy; monetary policy; economic constitution; macroeconomics; sustainability.

SUMARIO: 1. PLANTEAMIENTO.-2. ALGUNOS PRESUPUESTOS DE PARTIDA. 2.1. La economía como sistema. 2. 2. La estructural limitación del gasto. 2.3. La sostenibilidad como aproximación holística.-3. ORIGEN Y CONTEXTO DEL PRINCIPIO DE ESTABILIDAD PRESUPUESTARIA. 3.1. ¿De dónde viene la necesidad de incorporar un límite presupuestario al contenido de la constitución? 3.2. La estabilidad presupuestaria y el euro: conexión con la política económica y con la política monetaria.—4. LA ESTABILIDAD PRESUPUESTARIA EN EL CONTEXTO DEL MODELO ECONÓMICO CONSTITUCIONAL: EL REFORZAMIENTO DE LA PERSPECTIVA MACROECONÓMICA Y SU SOMETIMIENTO A DERECHO. 4.1. El modelo económico constitucional, estabilidad presupuestaria y macroeconomía. 4.2. Marco jurídico básico de la estabilidad presupuestaria: el techo de gasto como punto de partida.- 5 . EL PRINCIPIO CONSTITUCIONAL DE ESTABILIDAD PRESUPUESTARIA TRAS LA COVID-19: UNA OCASIÓN PARA REFLEXIONAR SOBRE SU ALCANCE Y DIFICULTADES. 5.1. La crisis de la COVID y sus efectos sobre el presupuesto. 5.2. La cláusula de excepción de la estabilidad presupuestaria. 5.3. Dificultades para la estabilidad presupuestaria y, en particular, para su cumplimiento en situaciones de excepción.-6. ALGUNAS REFLEXIONES CONCLUSIVAS. 7. BIBLIOGRAFÍA 


\section{PLANTEAMIENTO}

Como es bien sabido, en septiembre de 2011, la Constitución española (CE) fue modificada - con carácter exprés- para dar nueva redacción a su art. $135 \mathrm{CE}$. Se incorporó al texto constitucional, entre otras cosas, el principio de estabilidad presupuestaria. El contexto de la gran crisis financiera, como se le conoce, determinó aquella modificación, cuyo destinatario principal entonces fueron los mercados financieros internacionales así como las instituciones europeas e internacionales que, a la postre, terminarían rescatando la economía espańola bajo la modalidad de un rescate bancario, en mayo-junio de 2012. En aquel momento la situación de la deuda pública espańola en los mercados financieros internacionales comenzaba a ser preocupante: la prima de riesgo ${ }^{1}$ rozaba los 400 puntos básicos y aún llegaría a superar los 600 en mayo de 2012. El nuevo art. 135 CE recogía expresamente, y al máximo nivel constitucional, la garantía de la prioridad absoluta del pago de la deuda pública, en un claro intento de tranquilizar a los mercados.

Son, pues, muchas las perspectivas desde las que puede ser abordado el principio de estabilidad presupuestaria, empezando por la perspectiva jurídico-constitucional que analiza la reforma de la CE en 2011 y siguiendo por el estudio de su impacto en la economía española. Este trabajo se centra en el papel que la política económica asigna a la estabilidad presupuestaria, en el marco de la estabilidad económica a la que hace referencia el art. 40.1 CE y del fenómeno que supone la juridificación de la macroeconomía.

Con carácter general, al hablar de estabilidad presupuestaria me estoy queriendo referir a la situación de un presupuesto que se diseńa y se liquida en condiciones de equilibrio (ingresos igual a gastos) o con un déficit (más gastos que ingresos) asumible en un tiempo razonable. Es decir, un mayor gasto que se paga vía endeudamiento siendo este calculado en función de la riqueza futura estimada ${ }^{2}$.

En cuanto a la estructura del trabajo, dedicaré, con carácter previo, una primera parte a intentar hacer explícita mi aproximación y compresión del funcionamiento de la actividad económica.

Posteriormente, daré cuenta mínimamente del propio contenido del art. $135 \mathrm{CE}$, en el contexto de su interpretación sistemática, en el marco del modelo económico

1 La expresión "prima de riesgo" alude al sobreprecio que un país ha de ofrecer por encima del precio -o tipo de interés- de referencia del bono alemán para poder colocar sus emisiones de deuda pública en los mercados de deuda internacionales. Se estima que el bono alemán es el "más seguro", por lo que la prima sobre ese precio estaría indicando la confianza que los mercados muestran sobre la solvencia de un país. La prima de riesgo aumenta en la medida en que la inversión implica más riesgo, por ello es un indicador de la fortaleza o debilidad de una economía nacional.

2 Desde un punto de vista jurídico, se entiende por estabilidad presupuestaria la que aparece así definida en el art. 3.2 de Ley Orgánica 2/2012, 27 de abril de Estabilidad presupuestaria y sostenibilidad financiera (en adelante, LOEPSF); esto es, "la situación de equilibrio o superávit estructural". El art. 11 concreta, en sentido negativo, en qué consiste el déficit estructural como el déficit ajustado al ciclo, es decir, "el 0,4 por 100 del Producto Interior Bruto nacional expresado en términos nominales, o el establecido en la normativa europea cuando este fuera inferior". 
constitucional, para terminar abordando el papel que el principio de estabilidad presupuestaria tiene en el diseńo de la política macroeconómica y del objetivo constitucional de la estabilidad económica, al centrar el foco de atención en el impacto que la reforma constitucional tiene en el Derecho público y en la posición jurídica en que se pueden ver afectados poderes públicos y ciudadanos.

También es importante dar cuenta de lo que no tratará este trabajo, delimitando así negativamente su objeto. No se abordará aquí el debate sobre la oportunidad -o no- de incorporar este precepto en la Constitución ni del procedimiento seguido para ello ${ }^{3}$. Tampoco abordaré, no al menos con carácter específico, la relevancia que la reforma constitucional tiene sobre el modelo autonómico, aspecto que, hasta la fecha más ha ocupado a la doctrina iuspublicista, tanto en lo que hace a las relaciones Estado-CCAA ${ }^{4}$ como a las implicaciones que puede tener sobre la autonomía local, en particular a la vista de las profundas reformas legales que han afectado a ésta últi$\mathrm{ma}^{5}$. Asimismo, este trabajo tampoco aborda las cuestiones relativas al impacto que la aplicación de la estabilidad presupuestaria tiene sobre el modelo del Estado social ${ }^{6}$,

3 La reforma exprés de la Constitución en 2011 fue sin duda merecedora de no pocas críticas. Desde la perspectiva jurídica, véase por todos Juan Fernando LÓPEZ AGUILAR "De la Constitución "irreformable" a la reforma constitucional 'exprés", en Teoría y Realidad Constitucional, núm. 29, 2012, pp. 199 y ss. También Pía GARCÍA-ESCUDERO MÁRQUEZ, "La acelerada tramitación parlamentaria de la reforma del art. 135 de la Constitución", en Teoría y Realidad Constitucional, núm. 29, 2012, pp. 433-452; Martín BASSOLS COMA, "La reforma del artículo 135 de la Constitución española y la constitucionalización de la estabilidad presupuestaria: el proceso parlamentario de elaboración de la reforma constitucional", REDA, núm. 2-155, 2012, pp. 21-41 y Marc CARRILLO "Constitución y control de las finanzas públicas", $R E D C$, núm. 101, 2014, en particular, pp. 24-26. Todos ellos plantean reparos razonablemente fundados al procedimiento seguido. Con todo, el ATC 9/2012 de 13 de enero de 2012 ha convalidado y dado por buena la constitucionalidad del procedimiento de reforma constitucional; véase también Susana RUIZ TARRÍAS, Las dimensiones constitucionales de la Unión Económica y Monetaria Europea, Civitas Thomson Reuters, Pamplona 2016.

${ }^{4} \mathrm{Al}$ respecto, Tomás DE LA QUADRA-SALCEDO JANINI, "La incidencia de la reforma del artículo 135 de la Constitución sobre el Estado autonómico", Informe sobre Comunidades Autónomas, 2016, pp. 77-110; Carlo Alberto CIARALLI, "Límites del principio de estabilidad presupuestaria respecto de la autonomía financiera de las Comunidades Autónomas españolas", REALA Nueva Época, núm. 9, (2018), pp. 60-83. También, muy crítico, Joan PAGÈS I GALTÉS, "Análisis jurídico de la utilización de la estabilidad presupuestaria como límite del principio de autonomía financiera" Revista Catalana de Dret Públic (número especial), 2019, pp. 73-100.

5 En el caso de los entes locales, junto con la expresa mención que el art. 135.2 hace al equilibrio financiero, y su sometimiento a las exigencias de la LOEPSF, en 2013 fue aprobada, como es de sobra conocido, la Ley 27/2013, de 27 de diciembre, de racionalización y sostenibilidad de la Administración Local. El Tribunal Constitucional ha corregido en varias Sentencias el alcance de algunas de sus reformas, en orden a garantizar la autonomía local frente a algunos excesos del legislador, en concreto las SSTC, 41/2016, de 3 de marzo, 54/2017, 111/ 2016, 93/2017, de 6 de julio, 101/2017 de 20 de julio y 107/2017, de 21 de septiembre. Vid. la reflexión de Tomás FONT LLOVET y Alfredo GALÁN GALÁN, anterior a esta jurisprudencia, en "La reordenación de las competencias municipales ¿̨una mutación constitucional?”, Anuario del Gobierno Local 2013, 2014, pp. 8-9.

6 Sobre el particular, y especialmente crítico con la reforma, véase Gabriel MORENO GONZÁLEZ, Estabilidad presupuestaria y constitución. Fundamentos teóricos y aplicación desde la Unión Europea, Tirant lo Blanc, Valencia, 2019, pp. 439 y ss. 
en particular en momentos de crisis, ni la menos explorada perspectiva del impacto sobre el Estado democrático, que también lo tiene, más allá de algunas aproximaciones puntuales a este último aspecto. Por otra parte, la perspectiva relativa a la influencia del Derecho europeo solo se tratará en la medida en que sea necesario para la argumentación.

Por otro lado, el análisis del principio de estabilidad presupuestaria que aquí se va a abordar es solo una parte del contenido del nuevo art. $135 \mathrm{CE}$. Conviene recordar que en dicho precepto se incorporan otros contenidos, más novedosos incluso que el principio de estabilidad presupuestaria, la limitación al volumen de deuda pública o los límites al déficit público. Concretamente los siguientes:

a) la previsión de prioridad absoluta para el pago de la deuda, ya mencionada;

b) la específica forma en que se interpreta la estabilidad presupuestaria para el caso concreto de los entes locales como equilibrio presupuestario;

c) la encomienda al legislador estatal para aprobar una ley orgánica, con las consiguientes previsiones acerca de su contenido y su correspondiente impacto en el modelo de reparto territorial del poder, y

d) la propia mención a la Unión Europea en la Constitución Española, con las implicaciones que ello tiene.

Como era previsible, esta importante reforma constitucional ha dado lugar a una abundante reflexión. Inicialmente, fueron sobre todo los constitucionalistas quienes abordaron la cuestión ${ }^{7}$. También los tributaristas ${ }^{8}$, en particular aquellos que se han

\footnotetext{
7 Algunas revistas especializadas dedicaron, al poco de la aprobación de la reforma de la Constitución, sendos números monográficos a analizarla. Así por ejemplo es el caso del núm. 29 del Teoría y Realidad constitucional, publicado en 2012. O del núm. 93 de la Revista Española de Derecho Constitucional, publicado en 2011, donde se incluyen algo más de cincuenta páginas con las opiniones de un buen número de constitucionalistas. Estos autores dan ahí respuesta a tres preguntas que la Revista les formula en relación con: a) la base teórica a la que obedece la reforma, b) el procedimiento que se siguió, c) el desarrollo legislativo que habrá de llevarse a cabo, así como d) la oportunidad de llevar a cabo la citada reforma (pp. 159-210).

8 Destacan, entre otros, los trabajos de Violeta RUIZ ALMENDRAL, en concreto, "La reforma Constitucional a la luz de la Estabilidad presupuetaria", Cuadernos de Derecho Público, núm. 38, (2009), pp. 89-159 (conviene apuntar que la fecha que aparece en el número de la revista -ya desaparecidapuede dar lugar a cierta confusión; el artículo se envió y fue aceptada su publicación en febrero de 2012). También Esther MARCO PEÑAS, "Delimitación del sector público y estabilidad presupuestaria", Anuario de Derecho Municipal, núm. 12, 2019, pp. 219-243; M. ${ }^{a}$ Luisa ESTEVE PARDO, "El impacto del principio de estabilidad presupuestaria sobre los Gobiernos locales", en Anuario del Gobierno Local, núm. 1, 2012, número dedicado a "Racionalización y sostenibilidad de la Administración local: ‘̇es esta la reforma?”, pp. 153-172; Fernando DE LA HUCHA CELADOR, "La reforma del artículo 135 de la Constitución: estabilidad presupuestaria y deuda pública", Revista Española de Derecho Financiero, núm. 153, 2012, pp. 21-48; Miguel Ángel MARTÍNEZ LAGO, "Constitucionalización del principio de estabilidad presupuestaria en la Unión Europea y en España. La Ley Orgánica de Estabilidad Presupuestaria y Sostenibilidad Financiera”, en Diego LÓPEZ GARRIDO (dir.) y M. ${ }^{a}$ Luz MARTÍNEZ ALARCÓN (coord.), Reforma constitucional y estabilidad presupuestaria. El art. 135 del Constitución española, CEPC, Madrid, 2013, pp. 131-171 y Álvaro RODRIGUEZ BEREIJO, La Constitución fiscal de España, CEPC, Madrid, 2015 y más recientemente, del mismo autor, "Una
} 
dedicado más a los temas de derecho presupuestario -área, en principio, ocupada por esta disciplina, por más que la propia autonomía de la materia respecto del derecho administrativo sea dudosa ${ }^{9}$ - han escrito sobre el tema, en especial, aunque no solo, en relación con los problemas de financiación autonómica. En el campo del derecho administrativo también se han publicado algunos análisis ${ }^{10}$. No obstante, y salvo excepciones, el asunto no ha suscitado un especial interés entre los administrativistas. Y aún son escasos los trabajos que, desde el Derecho público, se centran en el impacto que esta reforma tiene en la configuración del modelo económico constitucional y en la determinación de la política económica y su sometimiento al derecho, como aquí se pretende.

Ciertamente el impacto y alcance que el principio de estabilidad presupuestaria tuvo en el momento de su incorporación a la Constitución y que sigue teniendo es grande, ${ }^{11}$ tanto política como jurídica y económicamente. Por otro lado, la situación concreta que se ha planteado, tanto en nuestro país como a nivel mundial, con ocasión de la pandemia de la COVID-19, ofrece la oportunidad de observar desde una perspectiva renovada el alcance de las obligaciones que se derivan de este mandato constitucional. La emergencia y excepcionalidad de la situación, así como la necesidad de tomar decisiones de gasto extraordinario para abordar la crisis sanitaria ${ }^{12}$, no debiera confundirnos en cuanto a la vigencia del principio. En mi opinión, el princi-

perspectiva constitucional del control del gasto público", Revista Española de Control Externo, núm. 58 2018, pp. 229-244. Susana RUIZ TARRIAS, Las dimensiones constitucionales de la Unión Económica y Monetaria Europea, Civitas Thomson Reuters, Pamplona 2016.

9 Sobre el particular, y entre otros, véase José Luis MARTÍNEZ LÓPEZ-MUNIZ, Introducción al Derecho administrativo, Tecnos, Madrid, 1986, pp. 155.

10 Destaca en este sentido el trabajo de Jorge GARCÍA-ANDRADE GÓMEZ, "La reforma del artículo 135 de la Constitución Española”, RAP, núm. 187, 2012, pp. 31-66. También Martín BASSOLS COMA, "La reforma del artículo 135 de la Constitución española y la constitucionalización de la estabilidad presupuestaria: el proceso parlamentario de elaboración de la reforma constitucional", REDA, núm. 2-155, 2012, pp. 21-41, y Antonio MARTÍ DEL MORAL, "La constitucionalización del principio de establidad presupuestaria", en Luis COSCULLUELA MONTANER, Luis MEDINA ALCOZ (dirs.) y María HERNANDO RYDINGS (coord.), Crisis económica..., op. cit., pp. 271-291. Trabajos todos ellos publicados en 2012. Sobre los aspectos institucionales, véase M. Mercè DARNACULLETA I GARDELLA, "Conseqüències institucionals de la limitació del deute públic a les comunitats autònomes i als Länder. Una anàlisi comparada dels mecanismes de control de l'estabilitat pressupostària a Espanya i Alemanya", Revista d'estudis autonòmics i federals núm. 20, 2014, pp. 74-213.

${ }^{11}$ Así apunta con acierto GARCÍA-ANDRADE, al señalar su "[p]otencial transformador sobre la regulación del Estado social y del derecho tributario", Jorge GARCÍA-ANDRADE GÓMEZ, "La aplicación del principio constitucional de estabilidad presupuestaria a las entidades locales", Luis COSCULLUELA MONTANER, Luis MEDINA ALCOZ, (dirs.) y María HERNANDO RYDINGS (coord.) Crisis económica y Reforma del Régimen Local, Civitas-Thomson Reuters, Cizur Menor, 2012, p. 307.

12 El 15 de junio de 2020, El País publicaba una entrevista a Kristalina Georgieva, directora gerente del FMI, en la que afirmaba: "[a]hora mismo el foco debe estar en salir de esta crisis con las mínimas cicatrices. Ustedes no oyen al FMI decir esto a menudo: gasten. Pero es lo que estamos diciendo a los Gobiernos: gasten tanto cuanto puedan, aunque guarden los recibos, asegúrense de que se rinden cuentas de cómo se usa el dinero. Y asegúrense también de que las medidas son temporales y tienen objetivos concretos". 
pio de estabilidad presupuestaria ha venido para quedarse; no se ha ido y reaparecerá para plantear sus exigencias en el momento en que la emergencia surgida en 2020 comience a controlarse, algo que ocurrirá antes o después.

\section{ALGUNOS PRESUPUESTOS DE PARTIDA}

\subsection{La economía como sistema}

La primera premisa es una aproximación de contenido principalmente económico: en concreto, que la economía funciona como un sistema. Aunque resulte una obviedad, creo que es importante recordarlo en este momento inicial. Esta consideración -generalmente aceptada en la ciencia económica- se encuentra en el sustrato de algunas de las conclusiones que más adelante se alcanzarán. No pretende ser una afirmación de carácter "experto". Es en parte resultado de la propia observación de la realidad, pero también del bagaje acumulado de los conocimientos teóricos en los que se asienta, con carácter general, la ciencia económica ${ }^{13}$. Por otro lado, y entre otras cuestiones, esta consideración, que arranca de la aplicación de la Teoría General de Sistemas a la economía, ha facilitado el uso de las matemáticas más avanzadas así como de la computación en la moderna ciencia económica. Precisamente el uso de las matemáticas, junto con el avance tecnológico en el área de la computación por parte de la ciencia económica, dota de carácter científico a sus propuestas, lo que en ocasiones logra eclipsar su condición de ciencia social, esto es, de ciencia que estudia el comportamiento humano.

Volviendo a la afirmación inicial: la economía es un sistema y además es un sistema abierto. Esto es, sus distintos elementos -o subsistemas-interaccionan entre sí y con el "ambiente", lo que da lugar a procesos de retroalimentación. Así, la mal llamada "economía real" - por contraposición a la economía financiera, que dicho sea de paso, también es real- incide en la marcha de la economía financiera. Cuando aquella crece, aumentan la riqueza, el ahorro y la inversión, lo cual impacta positivamente en los mercados financieros -bancarios y bursátiles-. Y al contrario, la recesión de la "economía real" se traduce en aumento de la morosidad, baja demanda de financiación, etc. Igualmente la economía financiera impacta y condiciona la "economía real", al determinar uno de sus factores de producción más relevantes: el coste de la financiación (medido en términos de tipo de interés).

Lo mismo puede sostenerse en relación con las interacciones entre la llamada economía privada y la economía pública, esto es, entre el sector privado y el sector público. A través de múltiples instrumentos bidireccionales, uno y otro sector encadenan sus efectos. Así, el nivel de la presión tributaria o el volumen del gasto público no solo pueden ser analizados desde la perspectiva del funcionamiento y evolución del sector público (incluido su cumplimiento o no de los compromisos de deuda y

\footnotetext{
13 Gregory MANKIW, Macroeconomía, 8. ${ }^{\mathrm{a}}$ ed., trad. de Esther RABASA, Bosch, Barcelona, 2014.
} 
déficit público, es decir de la estabilidad presupuestaria) sino desde sus efectos sobre la economía privada, ya sea como factores de impulso ${ }^{14} \mathrm{o}$, en su caso, de recesión, incluido el efecto crowding out ${ }^{15}$.

Igualmente, si observamos el fenómeno del sistema económico desde su perspectiva territorial e incorporamos a su análisis el factor de la globalización económica y de sus interacciones, la conclusión acerca de funcionamiento sistémico se acentúa más si cabe.

La condición de sistema abierto, antes citada, del sistema económico implica además que es especialmente sensible al impacto de fenómenos no estrictamente económicos, como la política, la estabilidad institucional, los desastres naturales y, de forma cada día más importante, al cambio climático, entre otros muchos. Esta afirmación queda hoy constatada al observar el impacto de la crisis sanitaria global en la economía mundial.

Particularmente relevante, en el contexto de esta reflexión, es la interacción entre la bien llamada politica monetaria ${ }^{16}$ y el sistema económico en su conjunto. Así como también entre el subsistema financiero ${ }^{17}$ y la "economía real”, ya mencionada.

14 A comienzos de otoño, en 2019, no era raro oír y leer comentarios acerca del impacto económico de la política de estímulos de 40.000 millones de euros que hizo público la canciller Angela Merkel el pasado 20 de septiembre de 2019, para potenciar un ambicioso plan de medidas ambientales.

A nivel estatal, en junio de 2020 -por poner un ejemplo- se habla de la Renta Minima Vital, aprobada por el Congreso, no solo como una medida de "justicia social" también como lo que los economistas llaman un estabilizador automático de la demanda, en la medida en que esos recursos revierten en el sostenimiento del gasto de la familias con efectos sobre el sector privado e, indirectamente también, sobre el sector público. Las ayudas para la compra de vehículos, recientemente anunciada por el Gobierno, sería otro ejemplo de cómo el gasto de sector público incide en la evolución del sector privado.

15 El efecto crowding out hace referencia al desplazamiento de la deuda privada en favor de la deuda pública. La rentabilidad y el menor riesgo que ofrecen los títulos de deuda pública los hace más interesantes para los inversores financieros, alejando así su interés en financiar a los inversores privados, que de ese modo encuentran encarecida y escasa la financiación en los mercados de valores. En este sentido, sector privado y sector público compiten por hacerse con la financiación que los mercados financieros ofrecen. La deuda pública, habitualmente, gozará de mejor calificación crediticia que la privada.

16 Al calificar como política, me estoy refiriendo al hecho de que en materia monetaria el comportamiento del mercado monetario está determinado inicialmente por decisiones políticas, esto es, de un poder público, y no como el resultado del encuentro entre la oferta y la demanda. Son los bancos centrales quienes operan a estos efectos como un poder público centralizado con capacidad para determinar por sí mismos la cantidad y precio del bien comerciado: su moneda nacional. A partir de ahí se desarrolla el mercado de divisas. Sobre las funciones de los bancos centrales, ver por todos, Charles GOODHART, The Evolution of Central Bank, Londres, 1988. También, Rosa M. ${ }^{a}$ LASTRA, International Financial and Monetary Law, 2. ${ }^{\mathrm{a}}$ ed., Oxford University Press, Oxford, 2015.

La reciente salida de Mario Draghi de la Presidencia del BCE ha ofrecido una interesante oportunidad para leer no pocos comentarios en la prensa especializada acerca de su función y del modo en que ha desempeñado su presidencia en los convulsos ańos de la crisis y después. Resulta interesante $-\mathrm{y}$ también algo inquietante- leer la entrevista a Luis de Guindos, actual vicepresidente del BCE, y sus reflexiones publicadas en El País el 26 de octubre de 2019, acerca de la "política en un banco central" y su interferencia.

17 Habla de esta interacción Sebastián MARTÍN-RETORTILLO, en "Sistema bancario y crediticio”, en Sebastián MARTÍN-RETORTILLO (coord.), Derecho Administrativo económico (vol. II), La 
Este aspecto o presupuesto es esencial en esta aproximación al concreto objeto de estudio del presente trabajo. De hecho, la reforma de la Constitución en 2011 trae fundamentalmente causa de la creación del euro y de las funciones que en materia de política monetaria han quedado transmitidas en favor de BCE a partir de 2001, como institución independiente ${ }^{18}$ respecto de los Estados miembros y del resto de instituciones europeas ${ }^{19}$.

El dinero, como bien intercambiado en el mercado financiero, es, hoy por hoy, un bien que se gestiona bajo un régimen de monopolio público cuyo operador es, en la mayoría de casos, el banco central de cada país. Su precio y cantidad se determinan en función de criterios técnico-políticos y no como resultado del encuentro de oferta y demanda, sin perjuicio del papel asignado por el sistema al llamado "mercado de divisas" ${ }^{20}$. El impacto de estas decisiones -incluso la mera sospecha o expectativa acerca de ellas ${ }^{21}$ - es directo sobre los mercados bursátiles y financieros, que toman como elemento de referencia el precio del bien-dinero (esto es, el tipo de interés) ${ }^{22}$.

Ley, Madrid, 1991, p. 93.

18 La referencia a la independencia del BCE lo es sin perjuicio de la coexistencia de vías o mecanismos de vinculación al poder público, aunque sea de efecto ciertamente restringido (designaciones o nombramientos sin facultades discrecionales de cese). En general sobre las Administraciones Independientes, me remito a Mariano MAGIDE HERRERO, Limites constitucionales de las Administraciones independientes, INAP, Madrid, 2000.

19 Tomando la expresión de MARTÍN-RETORTILLO, ésta -la estabilidad presupuestaria- llega en cierto modo arrastrada de la política monetaria, tras la creación del euro. En 1975, MARTíNRETORTILLO utilizaba la expresión para explicar cómo la política monetaria del Banco de España acabó "arrastrando" hacia sí la regulación bancaria, véase Crédito, banca y Cajas de Ahorro. Aspectos jurídico-administrativos, Tecnos, Madrid, 1975, p. 38.

20 El dinero, en tanto que bien intercambiado, determina su precio en el contexto de un mercado muy peculiar, en el que la oferta es resultado de la decisión de un único oferente (su banco central), lo que le otorga el control del precio (tipo de interés) mediante la fijación de la cantidad de dinero en circulación. En la medida en que la moneda nacional se intercambia además en el mercado internacional de divisas, las decisiones que cada banco central adopta han de considerar el efecto que tiene en la moneda la solvencia de la economía del país que representa. Sobre la historia del dinero y del mercado monetario, véase Charles P. KINDLEBERGER y Robert Z. ALIBER , Manias, pánicos y cracs: historia de las crisis financieras, traducción de B. RIBERA DE MADARIAGA, Ariel, Barcelona, 1991.

21 Es paradigmático en este sentido citar el impacto inmediato que tuvieron sobre el mercado de deuda las palabras de Mario Draghi en 26 de mayo de 2012, cuando afirmó: "haré todo lo que sea necesario para evitar la ruptura del euro y créanme será suficiente”. Aún tardaría un tiempo en poner en marcha el programa de expansión cuantitativa (QE, Quantitive Easing, en sus siglas en inglés) y el de compra de activos (deuda pública) por parte el BCE. Pero desde ese día, las tensiones en el mercado de deuda comenzaron a rebajarse.

22 Los actuales intentos por crear monedas "apolíticas", esto es, desvinculadas de un poder central, como es el caso del bitcoin, tienen a fecha de hoy una presencia residual en los mercados financieros. En un futuro, quién sabe. Así por ejemplo, la pretensión de Facebook de poner en marcha una moneda propia -la libra- ha puesto en alerta a los reguladores monetarios. De momento, el proyecto está parado. Probablemente no por mucho tiempo.

Ives Mersch, miembro del Consejo de Ejecutivo del BCE, en una conferencia impartida el 2 de septiembre de 2019, alertaba sobre los riesgos de este tipo de iniciativas -en referencia al proyecto libra-y de la necesidad de garantizar la seguridad y estabilidad del sistema financiero. El texto de la conferen- 
Pues bien, este funcionamiento sistémico de la economía -esquemáticamente expuesto- y la fuerte vinculación entre política monetaria, sistema financiero, deuda pública y, como expondré, el cumplimiento de los presupuestos del principio de estabilidad presupuestaria, configuran uno de los aspectos más importantes en esta aproximación de carácter previo. Dicho funcionamiento es, por otra parte, manifestación evidente de ese carácter abierto del sistema económico y de la interacción entre la "política" - en particular, la monetaria, aunque no solo-, el derecho y la economía.

\subsection{La estructural limitación del gasto}

Podría resultar ingenuo recordar la que sería la segunda idea o presupuesto de partida: no se puede gastar más de lo que se tiene ${ }^{23}$, si no es asumiendo el riesgo de una probable insolvencia. Ya sea en el ámbito privado como en el público, en el doméstico como en el empresarial, la responsabilidad y la prudencia exigen tomar en consideración esta restricción de partida. Cierto es que ello no impide el endeudamiento en las condiciones razonables de devolución, como experimentan cada día empresas y economías domésticas, en el bien entendido de que "lo que se tiene" puede calcularse y actualizarse incluyendo el ahorro del futuro. En definitiva, aquello que determina la capacidad de endeudamiento en el momento presente.

El sobreendeudamiento -a nivel privado y público- genera graves dificultades a quienes lo sufren -deudores y acreedores- y sus implicaciones económicas y sociales trascienden, interactuando nuevamente entre sí en el contexto sistémico de la economía -entre lo privado y lo público; lo financiero y lo "real"-. En los años anteriores, los rescates bancarios han sido la manifestación más visual del problema ${ }^{24}$.

Más allá del sentido común que, entiendo, subyace en la anterior afirmación, lo cierto es que la percepción acerca de los riesgos respectivos del sobreendeudamiento en el ámbito privado y en el ámbito público no son los mismos ni del mismo modo evidentes ${ }^{25}$.

cia puede consultarse en: https://www.ecb.europa.eu/press/key/date/2019/html/ecb.sp190902 aedded9219. en.html.

Este tipo de iniciativas evocan las tesis de Friedrich HAYEK, en La desnacionalización del dinero, traducción de LIAÑO, Instituto de Economía de Mercado Unión Editorial, Barcelona, 1983, donde propone la eliminación del sistema de monopolio público para la creación de moneda en manos de los bancos centrales y su sustitución por un sistema de competencia de mercado, donde los emisores de moneda compitan entre sí, en función de la solvencia de cada uno.

${ }_{23}$ Como han recordado Javier GARCÍA ROCA y Miguel Ángel MARTÍNEZ LAGO, "nadie puede pagar lo que no tiene", véase Estabilidad presupuestaria y consagración del freno constitucional al endeudamiento, Civitas-Thomson Reuters, Cizur Mayor, 2013, p. 248.

${ }_{24}$ El 2012, el rescate del sistema bancario español, llegó a resultas de una profunda situación de impagos y morosidad de deudores que se sobreendeudaron o, visto desde el otro lado, de una situación en la que los prestamistas infraestimaron el riesgo crediticio.

${ }^{25}$ Ver en este sentido, Álvaro RODRIGUEZ BEREIJO, La Constitución fiscal..., op. cit., pp. 79-89. 
En el caso del sobreendeudamiento privado, las consecuencias son claras: el impago, la insolvencia, el empobrecimiento..., incluida la morosidad trasladada y contagiada al conjunto del sistema bancario cuando dicho sobreendeudamiento se hace sistémico $^{26}$.

Sin embargo, en el caso del sobreendeudamiento público, la percepción que en ocasiones existe de que los recursos del sector público son cuasi-inagotables ${ }^{27}$ está, a mi juicio, en la base de algunas aproximaciones muy críticas con las limitaciones que impone la estabilidad presupuestaria ${ }^{28}$. Entre nosotros, quizá la falta de memoria de la historia, el hecho de que hayamos olvidado que la Hacienda Pública española ya quebró en más de una ocasión, ahonda en esta percepción. Es cierto que, con sus vaivenes, el crecimiento económico de los últimos 40 años en España, así como el desarrollo del sistema tributario y de las técnicas administrativas para su eficaz aplicación ${ }^{29}$, han servido de fundamento para un aumento del gasto público como no se había conocido antes. Y, en consecuencia, para la puesta en marcha de un modelo político-social en el que los derechos sociales -con sus carencias, por supuesto- se han podido costear razonablemente.

La crisis económica trajo nuevamente a la memoria y permitió contrastar con la realidad que también los Estados pueden quebrar -Grecia, Malta, Islandia...-. De repente, nos hemos encontrado con el problema del sobreendeudamiento, en este caso de los poderes públicos, y de las dificultades para pagar la deuda pública. Dificultades

26 Tanto es así que junto con las respuestas jurídico-privadas, el Derecho público ha reaccionado imponiendo obligaciones de información y transparencia que recaen sobre las entidades financieras a favor de los tomadores de créditos en la fase precontractual, con objeto de limitar y condicionar la concesión de créditos al consumo o hipotecarios. De este modo se da la paradoja de que quien otorga el crédito se ve obligado a ponerse en el lugar del cliente y velar por sus intereses (por los del cliente). El carácter tuitivo de este tipo de normas está afectando a la relación jurídico-privada de ciertos contratos y la posición de las partes en dichos contratos (derecho privado) así como al papel que el Derecho público sectorial se reserva para controlar y ordenar la actividad de las entidades de crédito y financiación.

Normas como la Ley 16/2011, de 24 de junio, de contratos de crédito al consumo y, la más reciente, Ley 5/2019, de 15 de marzo, reguladora de los contratos de crédito inmobiliario son ejemplos de esta marcada tendencia, de la que no es ajena ni el Derecho europeo ni la tarea llevada a cabo en los últimos años por los Tribunales. Sobre el particular, cabe mencionar los trabajos publicados en los últimos años por Matilde CUENA CASAS, en particular la obra colectiva dirigida por ella La prevención del sobreendeudamiento privado. Hacia un préstamo y consumo responsable, ed. Thomson-Aranzadi, 2017 y las colaboraciones ahí publicadas. También, de Matilde CUENA CASAS, "Intercambio de información positiva de solvencia y funcionamiento el mercado de crédito", InDret, 3/2017.

27 En sentido contrario, Stephen HOLMES y Cass R. SUSNSTEIN, The cost of Rights. Why liberty depends on Taxes, Norton \& Co, Nueva York, 1999. Está traducido al castellano El costo de los derechos. Por qué la libertad depende de los impuestos, Siglo XXI, Buenos Aires, 2011, p.153, para quienes "tomar en serio los derechos equivale a tomar en serio la escasez".

${ }^{28}$ Esta podría ser, entre otros argumentos de fondo, la idea que está en la base de tesis como las de Gabriel MORENO GONZÁLEZ, Estabilidad presupuestaria y constitución. Fundamentos teóricos y aplicación desde la Unión Europea, Tirant lo Blanch, Valencia, 2019, tremendamente críticas con las implicaciones que trae consigo el principio de estabilidad presupuestaria.

29 Incluso antes, desde la puesta en marcha de las políticas de estabilización a partir de 1959. 
agravadas, en el caso de los países de la eurozona, al carecer de moneda propia y no disponer ya del recurso a la devaluación y otras herramientas de política monetaria

Por otro lado, la receta de "subir los impuestos" para mantener el nivel de ingresos y reducir deuda, no puede obviar algo apuntado en el apartado anterior: la interacción de la economía privada y pública y los límites que ello implica. Tampoco los recursos tributarios son infinitos ${ }^{30}$.

Es cierto, no obstante, que existe, en el caso de las finanzas públicas, un factor distorsionante de la percepción sobre la financiación del gasto público. Me refiero al papel que la política monetaria puede llevar a cabo en relación con la "deuda pública". Esto es, la llamada "monetización de la deuda pública". Esta se produce cuando el banco central correspondiente compra deuda pública, la retira de mercado e "inyecta”, de ese modo, dinero en el sistema, convirtiendo la deuda pública en dinero ${ }^{31}$. Es un mecanismo habitual en el funcionamiento de los Bancos Centrales, en el ejercicio de su función de control de precios ${ }^{32}$. Este modo de operar de los Bancos Centrales facilita que se genere la percepción, antes señalada, de que el poder público puede "crear" dinero de la nada con el que financiar ilimitadamente sus gastos. Nuevamente los efectos sistémicos sobre la economía serán significativos. El primero y principal será la inflación, algo que directamente incide en la economía privada y en la renta

30 Como sabemos, la discusión política en este punto es intensa entre quienes sostienen recetas de bajada de impuestos para aumentar la recaudación con fundamento en la llamada curva de Laffer, medida propuesta desde los planteamientos liberales y quienes niegan dicho efecto. El tema suele, cada tanto, salir a la luz pública. Así, por ejemplo, ocurrió con el aumento de la recaudación que habría tenido lugar en Andalucía tras la bajada de impuestos que allí se adoptó por el gobierno de PP-Cs en otońo de 2019. La cuestión reside en saber si ese aumento fue resultado -o no- de las medidas tributarias o si responde a la confluencia de otros factores. Nuevamente, aparece la complejidad de las interacciones entre distintos factores y la dificultad de recetas simples. Y al contrario, la receta de subir los impuestos para equilibrar el presupuesto puede ser la solución... o no.

31 Sobre el particular, ver el interesante trabajo de Alberto RUIZ OJEDA "Monetización del déficit público y compra de deuda soberana por el BCE/SEBC. (A propósito de la jurisprudencia PringleGauweiler-Weiss del TJUE)", publicado en el num. 2/2020 de Indret. En él se da cuenta con detalle del fenómeno de monetización de la deuda y de sus consecuencias jurídicas, políticas y económicas. También, Jorge GARCÍA-ANDRADE GÓMEZ, "La cuestión prejudicial del Tribunal Constitucional alemán sobre la decisión OMT", Revista Española de Derecho Europeo, núm. 51, 2014, pp. 119-163 y del mismo autor, "El sistema monetario en una Unión Europea de Derecho", en M. a Amparo SALVADOR ARMENDÁRIZ (dir.), Regulación bancaria: transformaciones y Estado de derecho, 2014, Cizur Menor (Navarra), pp. 151-320. Y más recientemente, Agustín José MENÉNDEZ, “Qué clase de Unión es ésta? A vueltas con la saga Gauweiler", REDC, núm. 11266, 2019, pp. 269-299.

32 Por cierto, un instrumento en principio prohibido en el caso del BCE en virtud de lo dispuesto en los arts. 123 y 124 del TFUE. A pesar de lo cual, el BCE ha recurrido a mecanismos alternativos con una función semejante. Recordemos el efecto en los mercados de la frase de Draghi pronunciada el 26 de julio de 2012: "de acuerdo a nuestro mandato, el BCE está dispuesto a hacer lo que sea necesario para preservar el euro. Y créanme, será suficiente”. Posteriormente esta afirmación quedó confirmada con la puesta en marcha de las llamadas Operaciones Monetarias de Compraventa (OMC, esto es, compras de bonos condicionadas a la aplicación de determinadas reformas para los países rescatados y España) y más adelante, a partir de marzo de 2015, por el programa de compras de activos, conocido como QE -expansión cuantitativa-, destinado a impulsar la recuperación económica. Sobre el particular, me remito al trabajo de Jorge GARCÍA-ANDRADE GÓMEZ, “El sistema monetario...”, op. cit., pp. 151-320. 
de las personas (más inflación, menos renta en el bolsillo de los ciudadanos: lo que lo convierte en un impuesto encubierto, que ninguna ley tributaria regula directamente, ni respeta principio alguno del derecho tributario). Y el segundo, la pérdida de credibilidad de las economías nacionales que monetizan su deuda en el panorama de los mercados internacionales de divisas.

En definitiva, ninguna decisión es, pues, neutra en sentido económico. Todas, privadas y públicas, impactan en el sistema, generando reacciones, ya positivas, ya negativas, o de los dos tipos, depende dónde se coloque el foco. En todo caso, la consideración de que los recursos son escasos (recordemos aquello de que la economía es la ciencia que estudia las decisiones humanas para la optimización de recursos escasos) sobrevuela sobre cualquier decisión de carácter económico - pública o privada- o con impacto sobre la economía ${ }^{33}$.

Por lo que aquí respecta: el gasto público de un país estará en todo caso limitado al poder adquisitivo de la economía de dicho país, incluida su capacidad de financiarse en el futuro. Es decir, el gasto público -al igual que el privado- se encuentra estructuralmente limitado. Cuál sea el alcance -económico y jurídico- de esas limitaciones, con relación al déficit público y a la deuda pública, es ya otra cuestión.

\subsection{La sostenibilidad como aproximación holística}

Un tercer elemento apriorístico de esta aproximación tiene que ver con el nuevo paradigma de la sostenibilidad. La sostenibilidad es, por otra parte, efecto y consecuencia del carácter sistémico y de sistema abierto de la economía.

Por primera vez el nuevo art. $135 \mathrm{CE}$ ha incorporado esta expresión a la Constitución. Su apartado 4 la utiliza al tratar de los supuestos en los que será posible incumplir los "límites del déficit estructural y de volumen de deuda pública", en referencia al caso de que "perjudiquen considerablemente [...] la sostenibilidad económica o social del Estado".

El concepto de sostenibilidad es uno de esos conceptos que se ponen de moda, lo que no significa que se trate de una idea que carezca de sentido. Antes al contrario, ya que está cargado de realismo, razonabilidad y prudencia ${ }^{34}$, y está alineado, sin duda, a la satisfacción de los intereses generales. La preocupación por la sostenibilidad apareció inicialmente en el ámbito de la protección medio ambiental y del uso de los recursos naturales, significativamente, en el uso de la energía proveniente de

33 Las normas reguladoras sectoriales que imponen obligaciones a los operadores - p.ej. imponer a los bancos obligaciones de control y prevención de blanqueo de capitales- llevan consigo gastos e inversiones que no se dedican a otros destinos (efecto del coste de oportunidad), impactando así en su estructura de costes y beneficios.

34 Hace ya un tiempo José ESTEVE PARDO publicaba un sugerente artículo de prensa -ahora rescatado- que tituló “¿Es sostenible el Estado social”, en El Pais, aparecido el 24 de octubre del 2013. 
fuentes no renovables ${ }^{35}$. Pero lo cierto es que los objetivos de equilibrio, estabilidad, permanencia y durabilidad que subyacen en el fenómeno de la sostenibilidad en el caso de los recursos naturales han ido paulatinamente trasladándose a otros ámbitos. En particular y durante los años duros de la crisis, lo ha hecho al ámbito financiero, para el sector bancario, objetivo prioritario de las primeras grandes reformas ${ }^{36}$, tanto a nivel internacional como europeo y nacional.

La expresión sostenibilidad se ha convertido en un "tópico" de importancia y presencia creciente en todos los ámbitos ${ }^{37}$, políticos, económicos, sociales, académicos ${ }^{38}$ y, cada vez más, también jurídicos.

Volviendo al derecho español y junto con la previsión constitucional del art. 135.4 CE citado, esta expresión ya dio nombre, en 2011 , a un proyecto normativo de vocación integradora como fue la Ley 2/2011, de 4 de marzo, de economía sostenible ${ }^{39}$. Meses después, en septiembre, el nuevo art. $135 \mathrm{CE}$ incorporó la expresión a nuestra norma fundamental. Por su parte, la LOEPSF, que desarrolla el art. 135 de la CE, no solo incorpora la expresión en su título, también lo adjetiva, en referencia a la sostenibilidad financiera para el caso de las finanzas públicas. De este modo da un paso más allá de la estabilidad presupuestaria. Puede decirse que el objetivo de la

35 Es significativo que exista ya una Dirección General -la de sostenibilidad de la costa y el mar-, dependiente del Ministerio de Transición energética, que haya incorporado la expresión a su denominación. La adopción de la expresión alude ya a un planteamiento concreto y una orientación de las políticas públicas en ese ámbito. Imágenes no muy lejanas, como las del Mar Menor en otońo de 2019 con millones de peces muertos en sus orillas, dan cuenta de la necesidad de planteamientos de sostenibilidad, en concreto, en el ámbito de las costas y los mares.

36 En un trabajo que publiqué hace unos años, apuntaba ya en esta línea, véase "Transformaciones en la regulación bancaria: una perspectiva desde el Derecho público”, en José Luis COLINO MEDIAVILLA y José Carlos GONZÁLEZ VÁZQUEZ (dirs.), Las Cajas de Ahorro y la prevención y tratamiento de las crisis de las entidades de crédito, Comares, 2014, pp. 113-145.

37 Destacan en este sentido, los llamados 17 objetivos de desarrollo sostenible (ODS) que la ONU aprobó en 2015 con la mira puesta en 2030. El adjetivo "sostenible" aparece vinculado al uso de los recursos naturales (agricultura, agua, energía, océanos, mares y recursos marinos, bosques) y las estructuras de la vida actual, desde las ciudades a las industrias. Puede consultarse: https://www.un.org/ sustainabledevelopment/sustainable-development-goals/.

38 A modo ejemplo, cabe destacar el Sustainability Science Program del Mossavar-Rahmani Center for Business \& Government, de la Harvard Kennedy School y las iniciativas de investigación que promueve, inicialmente centradas en los aspectos medioambientales de los países en vías de desarrollo, pero que cada vez más ensancha su mirada al conjunto de la acción humana como pone de manifiesto el trabajo de William C. CLARK y Alicia G. HARLEY, Sustainability Science: Towards a Synthesis. Sustainability Science Program Working Paper 2019-01. Sustainability Science Program, John F. Kennedy School of Government, Harvard University, Cambridge, MA. https://www.hks. harvard.edu/sites/default/ files/centers/mrcbg/programs/sustsci/files/SSP2019-01.pdf.

Para estos autores, "sustainability science draws from a great variety of perspectives including traditional and practical knowledge, ecology and economics, engineering and medicine, political science and law, and a multitude of others". Todo ello compone una ambiciosa visión holística de la realidad y una metodología de análisis.

39 Con todo quizá, en aquellas fechas, a la pretendida vocación integradora y sistémica de la Ley había que añadir la necesidad de "vender" o hacer bueno un proyecto político de reformas frente a la crisis que, en otras circunstancias, hubiera encajado bajo el título habitual de Ley de Medidas. 
sostenibilidad -que la Exposición de Motivos de la LOEPSF califica como principio rector- busca una estabilidad presupuestaria permanente o, al menos, a medio plazo y, en todo caso, más allá de la anualidad presupuestaria. Es en realidad un objetivo más ambicioso que el exigido por el art. 135 CE. Como dice en su art. 1, se plantea "como garantía del crecimiento económico sostenido y la creación de empleo" ${ }^{40}$. Se trata, además, de una sostenibilidad distinta de la del art. 135. $4 \mathrm{CE}$, pues allí se la califica de "económica o social del Estado". En ese mismo sentido se menciona también en el art. 11.3 de la LOEPSF, desarrollando el supuesto que permitirá excepcionar el rigor de la estabilidad presupuestaria, en los casos de "catástrofes naturales, recesión económica grave o situaciones de emergencia extraordinaria que escapen al control de las Administraciones Públicas y perjudiquen considerablemente su situación financiera o su sostenibilidad económica o social". La LOEPSF, no obstante, fija las condiciones en las que esta cláusula podrá ser aplicada y juridifica un nuevo concepto económico, el de "recesión económica grave", cuya determinación queda vinculada a los parámetros formulados por la normativa europea. Por otra parte, añade un límite a la excepción: la "desviación temporal no puede poner en peligro la sostenibilidad fiscal a medio plazo". Aparece así otro tipo de sostenibilidad: la fiscal, y lo hace en esta ocasión como límite, a su vez, de la sostenibilidad económica y social.

Sostenibilidad ambiental, sostenibilidad de los recursos naturales, sostenibilidad energética, sostenibilidad financiera ${ }^{41}$, sostenibilidad económica, sostenibilidad fiscal, sostenibilidad social..., son facetas de una visión sistémica de la sostenibilidad en relación con la acción humana sobre su entorno. En particular la última, la sostenibilidad social, cobra fuerza en contextos de crisis humanitarias... y sanitarias. Son ya muchos los centros de investigación y expertos que trabajan y reflexionan en este ámbito $^{42}$.

La aproximación a una sostenibilidad sistémica, que incorpore la consideración conjunta de aspectos medioambientales, económico-financieros y sociales aparece como el próximo reto metodológico. La perspectiva de la sostenibilidad ańade a los análisis de todo tipo la variable temporal, construida mediantes estimaciones elaboradas a partir de datos actuales. La generalización de indicadores que miden los más

40 Conectaría en este sentido con el art. 40.1CE y el mandato que ahí se contiene dirigido a los poderes públicos que "promoverán las condiciones favorables para el progreso social y económico y para una distribución de la renta regional y personal más equitativa, en el marco de una política de estabilidad económica. De manera especial realizarán una política orientada al pleno empleo”. De hecho, para algunos autores existe una fuerte vinculación entre este art. $40.1 \mathrm{y}$ el nuevo art. 135, incluso al punto de apuntar que la estabilidad presupuestaria estaría ya en el art. 40.1. Véase infra nota 68.

${ }^{41}$ Como una manifestación más de esta preocupación, existe en marcha una Propuesta de Reglamento del Parlamento Europeo y del Consejo sobre el establecimiento de un marco para facilitar las inversiones sostenibles, COM/2018/353 final.

${ }^{42}$ Así, por ejemplo y por seguir con Harvard, El Mossavar-Rahmani Center for Business \& Government, de la Harvard Kennedy School, ha puesto en marcha un programa de investigación sobre COVID-19 and the Economy (accesible: https://www.hks.harvard.edu/centers/mrcbg/programs/covid-19). 
complejos parámetros ${ }^{43}$ y las metodologías de cálculo avanzadas que la computación actual permite, nos aproximan a la posibilidad de contar con este tipo de herramientas que faciliten la toma de decisiones que incluyan esta visión sistémica y holística.

En este sentido, en mi opinión, en el trasfondo del art. 135 CE y de sus implicaciones $^{44}$, aparece la idea de sostenibilidad como objetivo a medio y largo plazo. Ello obliga a hacer una aproximación dinámica del mandato de estabilidad presupuestaria, en el sentido de estabilidad sostenida en el tiempo. Pienso que en el futuro habremos de dedicar más atención a esta cuestión, en particular por lo que tiene de conexión con el principio democrático desde la perspectiva intergeneracional.

\section{ORIGEN Y CONTEXTO DEL PRINCIPIO DE ESTABILIDAD PRESUPUESTARIA}

\section{1. ¿¿De dónde viene la necesidad de incorporar un límite presupuestario al contenido de la Constitución?}

La preocupación por atender los problemas derivados del gasto público, del déficit público, del presupuesto..., en definitiva, de las finanzas públicas, está lejos de ser una novedad en el panorama constitucional comparado e histórico. Se trata además de un problema particularmente espinoso en el caso de los Estados compuestos -EEUU, Alemania y ahora la $\mathrm{UE}^{45}$-.

La disciplina - $\mathrm{O}$, en su caso, la indisciplina- en materia de gasto, la necesaria solidaridad entre las partes de los Estados compuestos, los posibles rescates ante situaciones de insolvencia... son elementos que históricamente han aparecido y han formado

43 Así por ejemplo, se alcanzaron las conclusiones en relación con los ocho Objetivos de Desarrollo del Milenio propuestos por la ONU en 2000. Véase el informe de 2015 sobre los Objetivos de Desarrollo del Milenio, elaborado a partir de los datos que suministra la United Nations Statistical Commission (accesible: https://unstats.un.org/unsd/statcom/). Sobre el uso de indicadores como instrumento para la adopción de decisiones, ver: Kevin. E. DAVIS, Angelica. FISHER, Benedict KINGSBURY y Sally E. MERRY, Governance by Indicators. Global Power through Quantification and Rankings, Oxford University Press, 2012. Posteriormente, este mismo grupo de investigadores ha publicado: Sally E. MERRY, Kevin. E. DAVIS. y Benedict KINGSBURY (eds.) The Quiet Power of Indicators. Measuring Governance, Corruption, and Rule of Law, Cambridge University Press, 2015.

44 En su trabajo, "La garantía del Estado frente a la crisis económica", publicado en $R A P$, núm. 2016, GARCÍA-ANDRADE GÓMEZ ya se refiere al principio constitucional de sostenibilidad económica como límite a la garantía del Estado, pp. 120-129. Desde otra perspectiva, principalmente económica, Tomás-Ramón FERNÁNDEZ también utiliza este concepto en "Reflexiones sobre a la sostenibilidad de los servicios públicos”, RAP, núm. 200, 2016, pp. 439-450.

45 Resulta especialmente esclarecedor el trabajo de Josu DE MIGUEL BÁRCENA, "Estabilidad financiera en entornos federales: la nueva Constitución económica del riesgo", Revista de Derecho Constitucional Europeo, núm. 26, julio-diciembre, 2016 y el interesante recorrido que hace de la experiencia norteamericana en el s. XIX y el modo en que se resolvieron en EEUU las tensiones entre las finanzas estatales y la hacienda federal. El resultado llevó a la incorporación de "frenos legales al endeudamiento" en las Constituciones de los Estados, ya a mediados del s. XIX (p. 29, versión accesible en internet). 
parte de las cuestiones políticas complejas. Afectan tanto al principio democrático ${ }^{46}$ como al principio autonómico, resultando ser una exigencia de la eficacia del funcionamiento político y económico de los Estados.

Desde este punto de vista, y aunque la crisis haya sido la "ocasión" para que el principio de estabilidad presupuestaria haya pasado a un primer plano constitucional en el derecho español, para nada estamos ante una cuestión novedosa ni ante un problema derivado de la "desregulación", como algunos han querido ver.

En este sentido, el caso alemán resulta significativo. En 2009, modificó su norma constitucional e incorporó reglas relativas a la estabilidad presupuestaria que han servido de orientación para nuestra reforma ${ }^{47}$.

La inclusión en un texto constitucional de un mandato limitativo dirigido a los poderes públicos en materia presupuestaria no es una novedad ni un hecho aislado ${ }^{48}$, siendo particularmente relevante en el caso de los Estados compuestos, como he señalado $^{49}$.

Por otro lado y al margen de las perspectivas jurídicas o políticas, en el marco del pensamiento económico, ya a comienzos de los ańos setenta, incluso antes, algunos renombrados economistas - de forma destacada, James E. Buchanan-comenzaron a señalar los problemas -no solo económicos, también jurídicos e incluso morales ${ }^{50}$ vinculados a la financiación de la deuda pública y abogaron por la incorporación de reglas fiscales en las Constituciones ${ }^{51}$.

Eran fechas en que los modelos macroeconómicos daban cuenta del funcionamiento de la economía en general utilizando modelos -como el modelo IS-LM, que muchos estudiamos en su día- que explicaban de forma relativamente sencilla la

46 Esta es la perspectiva que subyace bajo el conflicto jurídico-político que analiza Jorge GARCÍAANDRADE GÓMEZ, en "La cuestión prejudicial...", op. cit., pp. 119-163, en la pugna entre el TC alemán y el BCE.

47 Sobre el particular, ver Antonio ARROYO GIL, "La reforma constitucional de 2009 de las relaciones financieras entre la Federación y los Länder en la República Federal de Alemania”, Revista d'Estudis Autonòmics i Federals, núm. 10, 2010, pp. 40-71. Del mismo autor, "La cláusula de estabilidad presupuetaria: tras la senda constitucional alemana”, Cuadernos Manuel Giménez Abad, núm. 6, 2013, pp. 39-47. También, Manuel MEDINA GUERRERO, "La constitucionalización de la regla del equilibrio presupuestario: integración europea, centralización estatal”, Revista de Estudios Politicos, núm. 165, 2014, pp. 194-196.

48 Aunque no es una cláusula que esté generalizada, véase Gonzalo VILLALTA PUIG, "La constitucionalización del principio de equilibrio presupuestario: un análisis de derecho comparado", Revista las Cortes Generales, núm. 86, 2012, p. 176, sobre la situación de Alemania, Suecia, Chile, Hong Kong así como de algunos de los Estados norteamericanos.

49 Así lo apunta Josu DE MIGUEL BÁRCENA, J., “Estabilidad financiera en entornos ...”, op. cit.

50 Así señala en James M., BUCHANAM “Concerning Future Generations”, FERGUSON, J.M. (ed.) Public Debt and Future Generations, University of North Carolina Press, 1964, p. 55.

51 En 1995, tuvo ocasión de publicar James M., BUCHANAM, "Clarifying Confusion about the Balanced Budget Amendment”, National Tax Juournal, 1995, núm. 48 (3), pp. 347-350. 
interacción entre las políticas fiscales (gastos e ingresos) y las políticas monetarias ${ }^{52}$. Aquellos, y otros, modelos parecían dejar claras las ventajas de llevar adelante políticas económicas de corte ortodoxo. La idea de que las políticas económicas y fiscales, así como las finanzas públicas, funcionaban, en definitiva, al modo de una economía doméstica -esto es, donde no se puede gastar más de lo que se tiene y el endeudamiento queda limitado a la cantidad que razonablemente se prevé que se pueda devolver ${ }^{53}$-, motivaron la puesta en marcha de modelos de política económica ortodoxa, que incluían limitaciones como la regla de oro ${ }^{54}$ o el freno al endeudamiento. Se trataba de propuestas que depositaban su confianza en la validez de aquellos modelos matemáticos con atrayentes explicaciones de una realidad, por lo demás, compleja.

La crisis de las políticas keynesianas a finales de los años setenta y comienzos de los ochenta, así como su repercusión en la evolución de la deuda pública de muchos países, unido a las políticas promovidas desde instituciones internacionales -significativamente el FMI y el Banco Mundial- facilitaron que las ideas que abogaban por la necesidad de garantizar el equilibrio presupuestario comenzaran a extenderse, incorporándose en ocasiones también al máximo nivel normativo. Es significativo en este sentido el caso chileno ${ }^{55}$.

Recuperando la mirada hacia la situación de nuestro país, no debe olvidarse, como ya se ha apuntado, que el fenómeno de una Hacienda quebrada no es algo ajeno a nuestra historia. La Hacienda española ha suspendido el pago de su deuda en numerosas ocasiones - entre los siglos XVI y XIX- habiendo conocido las consecuencias nefastas que ello genera ${ }^{56}$.

Así pues, tanto desde la doctrina económica como desde el derecho y la política, lo cierto es que la preocupación por las finanzas públicas y por el equilibrio económico y presupuestario han sido cuestiones recurrentes. En España y en 2011 han acabado dando el salto hacia su juridificación y constitucionalización $n^{57}$.

52 El modelo IS-LM ve la luz en la década de los años 30 y surge a partir de la explicación propuesta por John Maynard KEYNES sobre el funcionamiento de la economía. Fue desarrollado por el economista John HICKS en 1937, poco después de que Keynes publicara su obra The General Theory of Employment, Interest and Money, en 1936.

53 Este es planteamiento que, por ejemplo, sigue abiertamente Gonzalo VILLALTA PUIG, "La constitucionalización de principio de equilibrio presupuestario...", cit. pp. 186-187.

${ }^{54} \mathrm{La}$ expresión "regla de oro", en el contexto de la política fiscal, alude a la limitación que implica que la emisión de deuda pública solo podrá financiar gasto en inversión (que repercutirá positivamente en las generaciones futuras) y no en gasto corriente. Conviene apuntar que en ocasiones esta expresión tiende a confundirse con la de equilibrio presupuestario incluso con estabilidad presupuestaria.

55 G. VILLALTA PUIG, "La constitucionalización del principio de equilibrio presupuestario...", op. cit., pp. 181-184 da cuenta del modo en que la Constitución chilena ha dejado recogida la regla de equilibrio presupuestario, incluidos requisitos formales (ley) para la aprobación de nuevos préstamos al ejecutivo, limitación de estos al mandato presidencial..., entre otras exigencias, que son desarrolladas en Leyes complementarias.

56 Véase por todos, Francisco COMÍN COMÍN, La crisis de la deuda soberana en España (15002015), Los Libros de la Catarata, Madrid, 2016.

57 Álvaro RODRIGUEZ BEREIJO señala que no habría parangón en el derecho constitucional de nuestro entorno en lo que se refiere a los principios constitucionales del gasto público (arts. 134, 135 y 136 
La juridificación ha llegado por diversas vías. La regla de la estabilidad presupuestaria, con sus efectos sobre el volumen de deuda pública y el nivel de déficit público, entre otros, comenzó imponiéndose a ciertos Estados como parte de los compromisos que adquirieron con el Banco Mundial o con el Fondo Monetario Internacional, con ocasión del apoyo económico y financiero recibido ${ }^{58}$. Su formulación en forma de "acuerdo" quedaba recogida en los memorándums de entendimiento que han dado cobertura legal a las relaciones jurídico-financieras que se entablan entre estos Estados receptores y el FMI ${ }^{59}$.

Por otro lado, la juridificación de esta regla ha tenido también lugar a través de instrumentos normativos de Derecho internacional, como ha sido el caso del propio TFUE $^{60}$ o del Tratado de Estabilidad, Coordinación y Gobernanza, firmado el 2 de marzo de 2012 (TECG, en adelante) ${ }^{61}$ así como de otros instrumentos normativos europeos, también de carácter vinculante. En esta segunda categoría destaca, de una parte, el llamado Six Pack de 1997, que recoge y desarrolla el Pacto de Estabilidad y Crecimiento y, posteriormente en 2011, el Pacto fiscal surgido con ocasión de la crisis.

Tanto en el caso del TECG como en el Pacto de Estabilidad y Crecimiento de 1997, España adquiría un conjunto de compromisos y condiciones cuyo contenido en lo sustancial coincide con que el que ha quedado recogido en el artículo $135 \mathrm{CE}$. De hecho, es en el TECG donde aparece el compromiso de los Estados firmantes de modificar y, en su caso, incorporar la mención expresa al principio de estabilidad presupuestaria al máximo nivel normativo ${ }^{62}$, aunque en el caso de Espańa la reforma constitucional ya había tenido lugar meses antes ${ }^{63}$.

$\mathrm{CE})$, que califica como una de las “innovaciones más interesantes de nuestra Constitución”, véase "Una perspectiva constitucional...", op. cit. p. 231.

58 Esta situación se dio en el caso de algunos países americanos, como parte del contenido de sus correspondientes $M O U$ (Memorandum of understanding) en la década de los ochenta y noventa.

59 Rosa M. ${ }^{a}$ LASTRA, International Financial and Monetary Law, 2. ${ }^{a}$ ed., Oxford University Press, Oxford, 2015.

${ }^{60}$ Véanse arts. 123 y ss. TFUE y el Protocolo núm. 12.

${ }_{61}$ Este Tratado fue ratificado por Espańa en 9 de agosto de 2012, y finalmente publicado en el BOE de 2 de febrero de 2013, una vez que entra en vigor. Sobre el particular, Francisco Jesús CARRERA HERNÁNDEZ, "El Tratado de Estabilidad, Coordinación y Gobernanza en la Unión Económica y Monetaria: ¿ un impulso a la realización de la Política Económica de la Unión Europea o un tratado superfluo e innecesario?”, RGDE, núm. 28, 2012.

${ }^{62} \mathrm{El}$ art. 3.2 de TECG prevé que: "[l] as normas establecidas en el apartado 1 se incorporarán al Derecho nacional de las Partes Contratantes a más tardar un año después de la fecha de entrada en vigor del presente Tratado mediante disposiciones que tengan fuerza vinculante y sean de carácter permanente, preferentemente de rango constitucional, o cuyo respeto y cumplimiento estén de otro modo plenamente garantizados a lo largo de los procedimientos presupuestarios nacionales".

63 Otros países europeos también modificaron su Constitución para acomodarse a estas exigencias. Es el caso de Italia, en 2012. Sobre el particular, Josu DE MIGUEL BÁRCENA, "La recepción constitucional de la cláusula de estabilidad presupuestaria en Italia. Comentario a las Sentencias 10/2015 y 70/2015 de la Corte Constitucional”, Revista Española de Derecho Constitucional, núm. 106, 2016, pp. 431-449. 
Como idea resumen de este epígrafe, puede decirse que lo novedoso en 2011, no ha sido tanto la propia regla de la estabilidad presupuestaria entendida como límite a las políticas fiscales, cuanto su constitucionalización y, en consecuencia, su elevación al máximo nivel normativo. Antes de 2011, el Reino de España, en el marco de sus compromisos internacionales ${ }^{64} \mathrm{y}$, sobre todo, europeos, había ya asumido la estabilidad presupuestaria para el diseño de sus políticas públicas y la formulación de sus cuentas públicas ${ }^{65}$.

\subsection{La estabilidad presupuestaria y el euro: conexión con la política económica y con la política monetaria}

Una vez apuntadas algunas cuestiones que están en el trasfondo del principio de estabilidad presupuestaria, lo cierto es que dicho principio afecta directamente al ejercicio de lo que, desde el punto de vista económico, referimos como politica fiscal. Política fiscal que bajo el presupuesto del funcionamiento sistémico de la economía, está directamente correlacionada con la política monetaria, siendo ambas, conjuntamente, instrumentos de la política económica. Así, desde el punto de vista de su eficacia económica, política fiscal y política monetaria se presentan como las herramientas macroeconómicas de la política económica.

Desde hace ya décadas, la explicación clásica de la macroeconomía y de la política económica de los países occidentales ha tenido lugar a través de modelos más o menos complejos, considerando dichas economías de forma relativamente aislada -no integradas en modelos globales- y disponiendo de moneda propia. Así, los objetivos que la política económica persigue -crecimiento de la renta nacional, estabilidad de precios, pleno empleo y una balanza de pagos equilibrada- pueden manejarse con dos "palancas": la fiscal, a través del presupuesto, y la monetaria, a través de la cantidad de dinero que existe en circulación y su tipo de interés. La flexibilidad y relativa opacidad que para la mayoría de los ciudadanos tienen los instrumentos de la política monetaria hacen que esta se presente como un instrumento político-económico muy preciado. La tentación de "darle a la máquina de hacer billetes" ha sido histórica-

64 Sin necesidad de ir más lejos, véase el propio contenido del TFUE y el Protocolo núm. 12.

65 Hay que recordar el papel que en su ya día tuvieron las Leyes 18/2001, de 12 de diciembre, General de Estabilidad Presupuestaria y la Orgánica 5/2001, de 13 de diciembre, complementaria de la anterior, como elemento de disciplina presupuestaria en el contexto de nuestra incorporación al euro. Sobre el particular, véase F. URÍA FERNÁNDEZ, "Una reflexión acerca de la constitucionalidad de las Leyes de Estabilidad Presupuestaria”, Revista de Derecho Público, núm. 12 (2001), pp. 117-137. El mismo autor, y tras haberse publicado la STC que avaló la constitucionalidad de las leyes de estabilidad presupuestaria, publicó: "Una sentencia oportuna e imprescindible. Comentario a la sentencia 134/2011, de 20 de julio, del Tribunal Constitucional, sobre determinados preceptos de las leyes de estabilidad presupuestaria”, en Eduardo GARCÍA DE ENTERRÍA y Ricardo ALONSO GARCÍA (coords.), Administración y justicia: un análisis jurisprudencial: liber amicorum Tomás-Ramón Fernández, vol. 1, 2012, pp. 373-395 
mente una tentación poderosa en manos de los Gobiernos ${ }^{66}$. Sus peligros fueron y son manifiestos. Desde la Alemania de entreguerras, a la Argentina de los ochenta o la actual situación de Venezuela, el recurso a imprimir billetes ha dado lugar a situaciones dramáticas y al empobrecimiento de la población, entre otras terribles consecuencias ${ }^{67}$. El uso de una y otra política requiere la alineación de los objetivos para poder generar un efecto sistémico positivo y armónico.

Es cierto que en los países occidentales, la consolidación de la creencia en los beneficios de una política monetaria neutra en manos de bancos centrales independientes ha ido afianzándose, ya desde el final de la Segunda Guerra Mundial, y limitando en consecuencia el alcance y uso de la política monetaria, como herramienta de la política económica. El paradigma de este modelo ha sido, sin duda, Alemania y su Bundesbank. La creación del euro supuso una aspiración y un reto para los países que se integraron en el proyecto. Formar parte de la zona euro, y de sus ventajas, implica la renuncia a disponer definitivamente de la política monetaria. Política y económicamente supone una clara cesión de soberanía, cediendo una de las potestades que con mayor arraigo identifican la propia configuración del modelo de Estado moderno ${ }^{68}$. La potestad monetaria es la formulación moderna, heredera del viejo señoreaje, uno de los más antiguos privilegios del monarca.

Obviamente las ventajas de la Unión Monetaria habrían de ser mayores que los sacrificios. Con todo, para el eficaz funcionamiento de la nueva moneda no bastaba la cesión por parte de los Estados miembros de la citada potestad. El artificio de una Unión Monetaria solo puede sostenerse razonablemente si el comportamiento de las economías de los Estados pertenecientes está dotado de la coherencia y sistematización propia de una economía estatal. De ahí se entiende el rigor de las condiciones iniciales para formar parte del club del euro ${ }^{69}$. Y de ahí viene también el compromiso

${ }^{66}$ Véase el trabajo de Alberto RUIZ OJEDA, "Monetización del déficit público y compra de deuda soberana por el BCE/SEBC. (A propósito de la jurisprudencia Pringle-Gauweiler-Weiss del TJUE)", op. cit.

${ }^{67}$ En 1922 Arthur R. G. SOLMSSEN, publicó su novela Una princesa en Berlín, un interesante relato que refleja dramáticamente las consecuencias de la hiperinflación que sufrió Alemania ente 1922 y 1923.

${ }^{68}$ Desde una perspectiva dogmático-jurídica, el concepto de soberanía choca abiertamente con la afirmación de que ésta pueda ser cedida. Cosa distinta serían las diversas potestades que el Poder soberano -y constituyente- asigna a los distintos Poderes constituidos, con los que se configura (se estructura y se forma) el Estado en su conjunto. En este sentido se manifiesta José Luis MARTÍNEZ LÓPEZMUÑIZ, en "Persistencia en la UE actual del fecundo proyecto originario", en Guillermo PÉREZ SÁNCHEZ (dir.) y María Belén MIRANDA ESCOLA y Begoña VIDAL FERNÁNDEZ, (coords.), La EU al cumplirse 90 años de la Declaración de Schuman, 1950-2020, Universidad de Valladolid, Valladolid, 2020, p. 259. El modo en que ha tenido lugar la integración de España en la Unión Europea, la naturaleza jurídica y el alcance jurídico de dicha Unión son aspectos intensamente debatidos, sobre los que no voy a entrar en este trabajo.

69 Según dispuso, en 1992, el Protocolo núm. 21 del TUE que concretó los criterios de convergencia del art. 121 TrCE, también introducido en ese momento por el Tratado de Maastricht y que estuvieron en vigor desde noviembre de 1993 
del pacto fiscal por la estabilidad y el crecimiento de 1997 al que se comprometen los Estados, en especial de la zona euro.

El euro ni se entiende ni se sostiene sin el Pacto fiscal ${ }^{70}$. Por esta razón las tensiones políticas y económicas surgidas con ocasión de la gran crisis fueron en Europa tan graves. Por ello también la situación de Grecia -en concreto su falta de rigor en el cumplimiento inicial de sus compromisos incluido el falseamiento de algunos de sus datos macroeconómicos- impactó como lo hizo en la situación económica de la eurozona. Solo así se explica que por aquellas fechas se llegara a hablar de la ruptura del euro, debido a las diferencias internas en el funcionamiento de las economías de los distintos Estados miembros.

En este sentido se ha de señalar la íntima relación existente entre el principio de estabilidad presupuestaria -ahora constitucionalizado- y la pertenencia de España a la eurozona. Desde esta perspectiva tampoco el compromiso constitucional de la estabilidad presupuestaria supone una novedad radical en la política económica, como se ha apuntado en el epígrafe anterior.

Para algunos autores es posible incluso llevar su recepción más atrás en el tiempo, argumentando que ya el art. 40.1 la Constitución española, al mencionar la estabilidad económica, habría incorporado un mandato que indirectamente estaría incluyendo una política fiscal y presupuestaria de estabilidad, aunque en este punto no existe consenso en la doctrina ${ }^{71}$.

En consecuencia, esta interacción entre las diferentes manifestaciones de la política económica -la política fiscal, con el presupuesto como herramienta básica, y la política monetaria- determina el modo de concebir el papel del presupuesto como elemento en el que se concretan los objetivos que la Constitución encomienda a los poderes públicos. Desde 1997, y expresamente a partir de 2011, esta tarea se lleva a cabo en el marco de los compromisos asumidos por España en el TFUE (en particular, el Protocolo 12) y en el TECG y el resto de normas europeas que lo desarrollan.

70 Un análisis de los antecedentes y consolidación del Pacto de Estabilidad y Crecimiento, así como del modo en que se entendió en la UE la relación entre la política monetaria y la política fiscal, en Gabriel MORENO GONZÁLEZ, Estabilidad presupuestaria y constitución..., op. cit.

${ }^{71}$ De hecho, son pocas - aunque autorizadas- las voces que, con ocasión de la reforma constitucional, han vinculado el principio de estabilidad presupuestaria con la estabilidad económica del art. 40.1 CE. Así, Antonio EMBID IRUJO, La constitucionalización de la crisis económica, Iustel, Madrid, 2012, p. 36; Martín BASSOLS COMA, "La crisis económica y sus repercusiones en el Derecho Público; el Principio de Buena Regulación Económica, supresión de cargas administrativas y constitucionalización de la estabilidad presupuestaria", Noticias de la Unión Europea, núm. 325, 2012, p. 12; Jorge GARCÍAANDRADE GOMEZ, "La garantía del Estado frente a la crisis económica", RAP, núm. 201, 2016, p. 129 y Luciano PAREJO ALFONSO (dir.) Lecciones de Derecho Administrativo. Orden económico y sectores de referencia, 3. ${ }^{\text {a }}$ ed. revisada y actualizada, Tirant lo Blanch, Valencia, 2012, p. 40. 


\section{LA ESTABILIDAD PRESUPUESTARIA EN EL CONTEXTO DEL MODELO ECONÓMICO CONSTITUCIONAL: EL REFORZAMIENTO DE LA PERSPECTIVA MACROECONÓMICA Y SU SOMETIMIENTO A DERECHO}

\subsection{El modelo económico constitucional, estabilidad presupuestaria y macroeconomía}

La anterior referencia al art. 40.1 CE sirve para conectar con la cuestión relativa al papel del nuevo art. 135 en la configuración del modelo económico constitucional ${ }^{72}$.

Vistos los antecedentes -cercanos y remotos- que enmarcan el principio de estabilidad presupuestaria que la reforma de 2011 constitucionalizó, puede decirse que este nuevo mandato avanza un paso en la formulación del citado modelo económico, al disciplinar su concreción (la de la estabilidad presupuestaria), cifrando el alcance del gasto presupuestado, así como la propia estructura de financiación del presupuesto. El alcance del gasto fiscal lo determinará anualmente el techo de gasto, cuya cifra viene condicionada por las previsiones de crecimiento del producto interior bruto (PIB, en adelante), de una parte, y el tope de déficit público, de otra. Así, estos

72 La doctrina ha reflexionado extensamente sobre este particular, desde los primeros momentos posteriores a la aprobación de la Constitución. La bibliografía es extensa, pero sirva como referencia general, la siguiente: el volumen colectivo, dirigido por Fernando GARRIDO FALLA, El modelo económico en la Constitución Español, Instituto de Estudios Económicos, Madrid, 1981; Juan Ignacio FONT GALÁN, "Notas sobre el modelo económico de la Constitución española de 1978", en RDM, núm. 152, 1979, pp. 205-239; Alberto ALONSO UREBA, La empresa pública. Aspectos jurídico constitucionales y de derecho económico, ed. Montecorvo, Madrid, 1985; Sebastián MARTÍN-RETORTILLO, Derecho Administrativo económico, vol. I, 2. a ed., La Ley, Madrid, 1991; Martín, BASSOLS COMA, "La Constitución económica", RDP, núm. 366, 1992, pp. 277-290; José María GIMENO FELIU, "Sistema económico y derecho a la libertad de empresa versus reservas al sector público de actividades económicas", RAP, núm. 135, 1994, pp. 149-212; Gaspar ARIÑO ORTIZ, Principios de Derecho Público económico. Modelo de Estado, Gestión Pública, Regulación económica, Marcial Pons/Idelco, Madrid, 1999; Manuel ARAGÓN REYES, Libertades económicas y estado social, McGraw-Hill Madrid, 1995. En una fase posterior, puede verse, entre otros, Germán FERNÁNDEZ FARRERES, "Reflexiones sobre el principio de subsidiariedad y la administración económica", en Estudios de derecho público económico: libro homenaje al prof. Dr. D. Sebastián Martín-Retortillo, Civitas, Madrid, 2003, pp. 165-184; en esta misma obra colectiva, José Luis MARTÍNEZ LÓPEZ-MUÑIZ, "La publicatio de recursos y servicios", pp. 687-718, así como Santiago MUÑOZ MACHADO, "Los límites constitucionales de la libertad de empresa", pp. 139-164; Enoch ALBERTÍ ROVIRA, "La constitución económica de 1978. (Reflexiones sobre la proyección de la Constitución sobre la economía en el XXV Aniversario de la Constitución española)", REDC, núm. 71, 2004, pp. 123-159; Luis ARROYO JIMÉNEZ, Libre empresa y títulos habilitantes, CEPC, Madrid, 2004; Antonio CIDONCHA, La libertad de empresa, Thomson/Civitas, Cizur Menor (Navarra) 2006; José ESTEVE PARDO, "La regulación de la economía desde el Estado garante", en Publicaciones de la Asociación Española de Profesores de Derecho Administrativo, ThomsonAranzadi, Pamplona, 2007, pp. 79 y ss.; José GARCÍA ALCORTA, La limitación de la libertad de empresa en la competencia, Atelier, Barcelona, 2008. También Santiago MUNOZZ MACHADO, "Fundamentos e instrumentos jurídicos de la regulación económica", en Santiago MUÑOZ MACHADO y José ESTEVE PARDO (dirs.), Derecho de la Regulación económica. I Fundamentos e Instituciones de la regulación, Iustel, Madrid, 2009, pp. 15-243, entre otros. 
límites condicionan la estructura de financiación (ingresos tributarios $v$ s ingresos no tributarios y financieros) del presupuesto.

Al concretarse de esta manera el marco en el que ha de moverse la capacidad de gasto de los poderes públicos, la Constitución está determinando también e indirectamente el alcance de las políticas públicas, al obligar a cada Gobierno a elegir el destino de sus recursos escasos ${ }^{73}$. Serán las preferencias políticas democráticamente representadas en cada momento -vía aprobación del presupuesto- las que otorguen prioridad a unos objetivos frente a otros. Para muchos autores la incorporación de este mandato constitucional habría implicado el triunfo del neoliberalismo de la Unión Europea. Partiendo de esta premisa, queda por concluir que el modelo económico inserto en la CE de 1978 habría "mutado" como consecuencia de la incorporación del art. $135 \mathrm{CE}$. En mi opinión, el asunto merece un análisis más complejo y matizado.

La reflexión acerca del modelo económico de la $\mathrm{CE}$ a la que estamos acostumbrados está formulada a partir de planteamientos propios de la microeconomía. Considera como sujeto a la empresa y reconoce su libertad para operar en los mercados, al tiempo que atribuye a los poderes públicos la tarea de ordenar su actividad y la de los mercados. Se presenta, en ocasiones, como una suerte de confrontación entre los derechos de los ciudadanos y las empresas, por una parte, y, por otra, la posición jurídica de las AAPP en relación con dichos sujetos, en su función de garantía de los intereses generales (desde la protección del consumidor, a la protección medioambiental, pasando por el buen funcionamiento de los mercados o a la garantía de prestación de los servicios esenciales, entre otros intereses generales dignos de protección). Se plantea pues como una dinámica en la que el alcance de las libertades económicas se armoniza con el interés general por medio de las potestades de intervención de los poderes públicos. Es decir, el modelo económico constitucional es el resultante de esta concepción jurídica sobre el contenido de los derechos reconocidos a los ciudadanos y empresas y las relaciones jurídico-económicas que se generan entre estos, en el marco de las posibles restricciones o condicionantes establecidos al servicio del interés general.

Con todo, la visión de la economía desde la "macroeconomía" también se atisba en algunos pasajes de la Constitución española. Lo hace inicialmente en su preámbulo, cuando se refiere al orden económico y social justo, e indirectamente cuando menciona el progreso de la cultura y de la economía para asegurar a todos una digna calidad de vida. También, el propio art. 38, que reconoce la libertad de empresa en el marco de la economia de mercado, recoge esta perspectiva cuando menciona las exigencias de la economía general. Obviamente está presente en el art. 40.1 ("Los poderes públicos promoverán las condiciones favorables para el progreso social y económico y para una distribución de la renta regional y personal más equitativa, en el marco de una política de estabilidad económica. De manera especial realizarán una política orientada al

73 Para algunos y de modo simplificado es tanto como decir que la Constitución estaría imponiendo un modelo en el que la economía condiciona la política. 
pleno empleo"). Por su parte, y en sede de reparto competencial, el art. 148.13 CE menciona el "fomento del desarrollo económico de la Comunidad Autónoma dentro de los objetivos marcados por la política económica nacional”, mientras que los arts. 148.7 CE y 140.1.13a CE se refieren respectivamente a la "ordenación general de la economía y a la planificación general de la economía”.

También el art. $131 \mathrm{CE}$, que regula la planificación de la actividad económica general, se aproxima a la realidad económica desde esta perspectiva macroeconómica. El plan, como instrumento de dirección económica, tal y como está diseñando en la Constitución, se concibe al servicio de "las necesidades colectivas, [para] equilibrar y armonizar el desarrollo regional y sectorial y estimular el crecimiento de la renta y de la riqueza y su más justa distribución" ${ }^{74}$.

La expresión "riqueza" 75 o "renta" en el sentido que le otorga la ciencia económica -como variable que mide la evolución y el bienestar económico- aparece expresamente en los arts. 40 y $131 \mathrm{CE}$. Al menos en todas estas referencias, la Constitución estaría contemplando la economía en su aproximación macroeconómica.

La reforma constitucional de 2011 ha venido a completar esta perspectiva, al incorporar y "juridificar" conceptos típicamente "macroeconómicos", como son los de producto interior bruto, déficit estructural (del presupuesto se entiende), volumen de deuda pública, o recesión económica ${ }^{76}$. En el nuevo art. $135 \mathrm{CE}$ el uso de estos conceptos se encuentra al servicio de mandatos cuyos destinatarios son los poderes públicos, siendo por tanto expresión típica del Derecho público.

74 En relación con el art. 131 CE y su significado me remito al trabajo de Martín BASSOLS COMA, "La planificación", en Fernando GARRIDO FALLA, El modelo económico en la Constitución Español, Instituto de Estudios Económicos, Madrid, 1981, así como al extenso capítulo que dedica a la planificación Sebastián MARTÍN-RETORTILLO, en su Derecho Administrativo económico (vol. I), La Ley, Madrid, 1991 pp. 325 y ss.

75 La expresión riqueza también aparece en el art. 128.1 ("Toda la riqueza del país en sus distintas formas y sea cual fuere su titularidad está subordinada al interés general”), pero con distinta función.

76 El concepto recesión económica aparece recogido en el art. 135.4, que regula la cláusula de excepción del régimen previsto para la estabilidad presupuestaria. Se prevé que "los límites de déficit estructural y de volumen de deuda pública solo podrán superarse en caso de catástrofes naturales, recesión económica o situaciones de emergencia extraordinaria que escapen al control del Estado y perjudiquen considerablemente la situación financiera o la sostenibilidad económica o social del Estado, apreciadas por la mayoría absoluta de los miembros del Congreso de los Diputados".

Entre los economistas, la recesión económica viene interpretándose como dos trimestres consecutivos de decrecimiento económico. Conviene distinguir la recesión económica de la desaceleración económica, situación en la que la renta o PIB sigue creciendo pero a tasas menores y de depresión económica, situación que se vincula con una caída del 10 por 100 del PIB en un año. Esos conceptos son de uso común en teoría económica; algunos de ellos se han convertido en conceptos jurídicos con lo que ello conlleva. Menos precisos son, sin embargo, los perfiles del concepto crisis económica.

Por su parte, el art. 11.3, párrafo 2 de la LOEPSF, considera que "recesión económica grave se define de conformidad con lo dispuesto en la normativa europea. En cualquier caso, será necesario que se dé una tasa de crecimiento real anual negativa del Producto Interior Bruto, según las cuentas anuales de la contabilidad nacional”. En este sentido, es más exigente. 
La novedad radica en que los principios que orientan la política con impacto en la macroeconomía han pasado ahora a ser mandatos concretos, con las dificultades que ello implica al tratarse de algo tan complejo como la macroeconomía. Bien es cierto que la Constitución española no ha configurado un derecho subjetivo de los ciudadanos a la estabilidad presupuestaria, ni un cauce jurisdiccional ordinario que pudiera permitir forzar su cumplimiento por vía judicial y, menos aún, un régimen sancionador ${ }^{77}$. No obstante, no por ello el mandato del art. 135 CE deja de ser vinculante. En primer lugar, porque sí caben controles judiciales ordinarios en el caso de los conflictos interadministrativos, así como, en su momento, el control de la jurisdicción constitucional.

Como es sabido, el mandato del art. $135 \mathrm{CE}$ requiere de un desarrollo legal -de carácter orgánico- del que se encarga la LOEPSF. Aunque la LOEPSF no es propiamente una norma de carácter competencial ${ }^{78}$, sí regula las relaciones interadministrativas en relación con el ejercicio de la tarea presupuestaria -Estado-CCAA-EELL-y tiene, además, carácter organizativo-funcional; es en este sentido una norma propia de un Estado compuesto. Podría incluso discutirse si forma o no parte de lo que, en una expresión ciertamente confusa, viene entendiéndose como bloque de la constitucionalidad. En todo caso, no cabe duda que en este ámbito, el art. $135 \mathrm{CE}$ tiene su correspondiente impacto en el diseńo del modelo autonómico.

En este sentido puede afirmarse que la macroeconomía ha pasado a formar parte de lo que el Derecho público regula, y que lo ha hecho al máximo nivel ${ }^{79}$, sumándose a las cláusulas constitucionales de las que se deduce el modelo económico constitucional ${ }^{80}$.

La mención al marco de una politica de estabilidad económica del art. 40.1 estaría ya, al menos indirectamente, determinando un modelo macroeconómico que incluye el crecimiento de la renta, la estabilidad de los precios, el pleno empleo y una balanza de pagos equilibrada, típicos conceptos de la macroeconomía. Con

77 Todo el capítulo IV de la LOEPSF, que contempla las medidas preventivas, correctivas y coercitivas, está diseñado para garantizar el cumplimiento de la estabilidad presupuestaria de CCAA y EELL como potestad atribuida al poder central. El principio autonómico determina los límites de esta potestad. Y en todo caso, nada se dice para el caso de que el incumplimiento venga de la AGE. En ese caso, la tarea de control salta las fronteras nacionales y se traslada a las instituciones europeas, y a la aplicación de las normas relativas al procedimiento del déficit excesivo.

78 Sobre esta cuestión, me remito al ya citado trabajo de Tomás DE LA QUADRA-SALCEDO JANINI, "La incidencia de la reforma...”. También, Javier GARCÍA ROCA y Miguel Ángel MARTÍNEZ LAGO, "La repentina constitucionalidad de la Ley de Estabilidad presupuestaria según la STC 215/2014, de 18 de diciembre", REDE, núm. 54, 2015, pp. 89-122 y Fernando DE LA HUCHA CELADOR, "Artículo 135 CE: Estabilidad presupuestaria y deuda pública", Tribuna en Diario La Ley, 14 de diciembre de 2018.

79 En este sentido, aconsejo la lectura del interesante trabajo de Jorge GARCÍA-ANDRADE GÓMEZ, "La regulación de la macroeconomía: un desafío para el derecho público", de próxima publicación y que he tenido ocasión de consultar pro manuscrito.

80 En el sentido dado por Manuel GARCÍA PELAYO, "Consideraciones sobre la cláusulas económicas de la Constitución" en Manuel RAMÍREZ, Estudios sobre la Constitución Española de 1978, Pórtico, Zaragoza, 1979, pp. 27 y ss. 
todo, una política económica con estos objetivos, a mi juicio, no necesariamente exige una concreción de la estabilidad presupuestaria como la que recoge ahora el art. $135 \mathrm{CE}$, que mira en definitiva a unas finanzas públicas sostenibles en el tiempo. Hay que considerar que la idea de estabilidad económica a la que aludía el art. 40 en 1978 venía determinada por el pensamiento económico dominante en ese momento, muy centrado en las políticas de pleno empleo -en la medida en que el desempleo implicaba la infrautilización de recursos y condicionaba el crecimiento económico, tirando de la demanda hacia abajo-. La visión predominante era cortoplacista, muy en línea con el keynesianismo dominante. En 2011, y más si cabe en 2020, se impone la idea de estabilidad sostenible, de modo que, por fin, el medio y largo plazo han entrado a formar parte de la ecuación, con efectos sobre el modelo económico constitucional.

Más allá, por tanto, de si la regulación de la actividad de los poderes públicos desde la perspectiva de sus efectos sobre la macroeconomía ya formaba parte o no del modelo económico en la Constitución, lo cierto es que la reforma de 2011 da lugar a un evidente reforzamiento de esta perspectiva. En este sentido, en 2011, la Constitución Española, al modificar el art. $135 \mathrm{CE}$, acomoda el texto constitucional al tiempo actual y, como ocurrió en 1978, a las ideas y al pensamiento económico dominante del momento. Prueba de ello es el amplio consenso con que fue aprobada la reforma y con el que se ha buscado posteriormente su aplicación.

La crisis de la COVID-19 sin duda marcará un antes y un después. Y ciertamente va a ser ocasión de testar la vitalidad del modelo y a nadie se le escapan las dificultades que ha supuesto y va a suponer para la economía y su evolución. Junto con la COVID-19, como causa de la nueva crisis económica, en mi opinión la presencia en el plano de la primera línea de la política de ideas de corte marcadamente comunista, representadas por la participación de Unidas Podemos en el Gobierno de coalición con el PSOE -recuérdese, promotor de la reforma de 2011-, pudiera trasladar la equivocada conclusión de que la vigencia del modelo constitucional de disciplina presupuestaria habría pasado a formar parte del contenido constitucional olvidado, como ha ocurrido, por ejemplo, con el art. $131 \mathrm{CE}$. En los próximos meses habrá ocasión de comprobar el real alcance de este modelo constitucional macroeconómico. Me atrevo a pronosticar que la necesidad de recursos financieros y de acceso a los fondos europeos darán lugar, antes o después, a un baño de realidad. No es que la economía se imponga sobre la política, es que no se puede gastar más de lo que se tiene ${ }^{81}$.

81 Por otra parte, y al margen de las razones políticas y económicas, no son contenidos constitucionales comparables. Desde la perspectiva jurídica, la planificación en el art. 131 está expresamente prevista como posibilidad; la estabilidad presupuestaria del art. 135 como exigencia obligatoria. Aquella podrá "olvidarse" por la falta de uso, pero no cabe posibilidad de "olvido" de esta, pues su inaplicación viola directa y manifiestamente lo preceptuado por la Constitución. 


\subsection{Marco jurídico básico de la estabilidad presupuestaria: el techo de gasto como punto de partida}

Los principios materiales que tradicionalmente han informado el derecho presupuestario -con fundamento en los arts. 134 y $31.2 \mathrm{CE}$ - se han visto ahora reinventados por las exigencias del art. $135 \mathrm{CE}$. El art. 135 impone exigencias de contenido material y estructural, que condicionan, de una parte, la cuantía -el coloquialmente llamado techo de gasto ${ }^{82}-\mathrm{y}$, de otra, la estructura de los ingresos (ingresos tributarios $v s$ ingresos no tributarios y financieros).

Hasta 2011, la Constitución del 78 no fijaba límite al endeudamiento, aunque sí imponía principios materiales al gasto público (economía y eficiencia), a lo que habría que añadir, además, los principios generales informadores de la actuación de los poderes públicos del art. 103.1 CE, que indirectamente también hacen referencia a la racionalidad de la actuación de la que no es ajena la racionalidad económica. Otra cosa es que la justiciabilidad a partir de estos principios siempre ha resultado difícil.

A partir de 2011, los nuevos límites que el modificado art. 135 CE impone se manifestarán a lo largo de todo el proceso presupuestario -elaboración, aprobación y gestión- ${ }^{83}$. El marco jurídico es el que viene determinado por lo previsto en la Ley 47/2003, General Presupuestaria y, ahora también, en la LOEPSF de 2012.

En este punto aparece el "techo de gasto", que contempla el art. 15 de la LOEPSF, como punto de partida de todo el iter presupuestario.

Según ahí se prevé, se fijarán mediante acuerdo del Consejo de Ministros

"los objetivos de estabilidad presupuestaria, en términos de capacidad o necesidad de financiación de acuerdo con la definición contenida en el Sistema Europeo de Cuentas Nacionales y Regionales, $y$ el objetivo de deuda pública referidos a los tres ejercicios siguientes, tanto para el conjunto de Administraciones Públicas como para cada uno de sus subsectores. Dichos objetivos estarán expresados en términos porcentuales del Producto Interior Bruto nacional nominal” (art. 15.1. LOEPSF).

82 La expresión techo de gasto no aparece como tal ni en la CE ni en la LOEPSF. No es pues propiamente en un concepto legal. Lo que sí aparece es, en el art. 30, la mención al "límite de gasto no financiero" que deben aprobar Estado, CCAA y EELL y que "marcará el techo de asignación de recursos de sus Presupuestos". Entiendo que la expresión techo de gasto alude a la cantidad total que se prevé gastar, incluida la devolución de la deuda - gastos financieros-, y que viene determinada como un porcentaje del PIB nominal (art. 15.1 LOEPSF) estimado. Dado que la partida de gastos financieros -devolución de la deuda pública- es fija (el art. 135.3, párrafo 2 ${ }^{\circ}$ CE garantiza la inclusión de estos créditos "en el estado de gastos de sus presupuestos"), es el gasto no financiero el que, en su caso, variará y será determinante en el cálculo de techo de gasto.

${ }^{83}$ Así prevé el art. 26.1 de la LGP, al tratar de los Principios y reglas de programación presupuestaria, donde establece que: "La programación presupuestaria se regirá por los principios de estabilidad presupuestaria, sostenibilidad financiera, plurianualidad, transparencia, eficiencia en la asignación y utilización de los recursos públicos, responsabilidad y lealtad institucional, conforme a lo dispuesto en la Ley Orgánica 2/2012, de 27 de abril, de Estabilidad Presupuestaria y Sostenibilidad Financiera." Este texto proviene de la modificación incorporada en 2012 en virtud de la LOEPSF. Esta modificación solo cambió la redacción original, incorporando la referencia a la Ley. Y añadió también, como novedad, la expresa mención a los principios de responsabilidad y lealtad institucional. 
La LOEPSF prevé que el acuerdo sea remitido a las Cortes Generales, para su debate en pleno, tanto en el Congreso como en el Senado. Serán las Cámaras -ambas y por separado ${ }^{84}$ - las que aprueben o rechacen el acuerdo (art. 15.6 LOEPSF).

Una vez determinados los objetivos de estabilidad presupuestaria y deuda públi$\mathrm{ca}$, la elaboración de los presupuestos generales de las AAPP habrá de acomodarse a dichos objetivos (art. 15.7 LOEPSF). Aprobado el techo de gasto, el Ministerio de Hacienda y Administraciones Públicas, previo informe de la Autoridad Independiente de Responsabilidad Fiscal (AIReF, en adelante) ${ }^{85}$, formulará una propuesta en la que se concretarán los objetivos de estabilidad presupuestaria y deuda pública para cada CCAA (art. 16. LOEPSF). Esta propuesta, dirigida previamente al Consejo de Política Fiscal y Financiera, será la que finalmente corresponderá aprobar al Gobierno.

Precisamente en relación con estos acuerdos y su naturaleza jurídica, el Pleno de la Sala 3. ${ }^{a}$ del TS ha tenido ocasión de manifestarse en sus SSTS de 10 de mayo de 2016. Cataluña, Andalucía, Canarias y Asturias interpusieron sendos recursos contencioso-administrativos frente a cinco acuerdos del Consejo de Ministros adoptados entre julio y octubre de 2013 en relación con la fijación del techo de gasto y de deuda pública para $2014^{86}$. Entre ellos se incluía el previsto en el art. 15.1 LOEPSF,

84 Precisamente esta exigencia -la necesidad de que el Acuerdo sea aprobado por ambas cámarasprovocó que el 27 de julio de 2018 el Senado rechazara el techo de gasto presentado por el Gobierno de Sr. Sánchez. Con posterioridad, el 24 de agosto de 2018, el Grupo Socialista en el Congreso presentó una Proposición de Ley (BOCG, de 7 de septiembre de 2018) con objeto de modificar la LOEPSF en este punto, previendo que en caso de rechazo por el Senado, el Acuerdo volviera al Congreso donde finalmente podría ser aprobado por mayoría simple.

La tramitación de esta Propuesta de Ley solicitaba a la Mesa del Congreso su tramitación por el procedimiento de urgencia y lectura única, propuesta que fue desestimada. La Diputada Adriana Lastra presentó recurso de amparo ante el TC que finalmente resolvió el 2 de octubre de 2019, desestimando dicho recurso.

85 La creación de la AIReF tuvo lugar en virtud de la Ley Orgánica 6/2013, de 14 de noviembre, de creación de la Autoridad Independiente de Responsabilidad Fiscal. En su Exposición de Motivos se menciona la "Directiva 2011/85/EU, del Consejo, de 8 de noviembre de 2011, sobre los requisitos aplicables a los marcos presupuestarios de los Estados Miembros" y la exigencia que en ella se contiene "de contar con instituciones fiscales independientes que realicen el ejercicio de un seguimiento efectivo del cumplimiento de las reglas fiscales", como fundamento, entre otros, de esta iniciativa. Sobre el particular, me remito a Juan CALVO VÉRGEZ, "La creación de la nueva autoridad independiente de responsabilidad fiscal en torno al alcance de sus informes y opiniones", Revista Aranzadi Doctrinal, núm. 11 (marzo), 2014, pp. 61-75; Miguel Ángel MARTÍNEZ LAGO, "Reglas fiscales y organismos independientes de supervisión: la Autoridad de responsabilidad fiscal española", en Francisco David ADAME MARTÍNEZ y Jesús RAMOS PRIETO (coords.), Estudios sobre el sistema tributario actual y la situación financiero del sector público: homenaje al Profesor Dr. D. Javier Lasarte Álvarez, Ministerio de Hacienda e IEF, Madrid, 2014, pp. 61-75 y Antonio-Martín PORRAS GÓMEZ, "La posición de la Autoridad Independiente de Responsabilidad Fiscal en el sistema constitucional de control financiero", REDC, núm. 110, 2017, pp. 143-163.

86 Son cinco Sentencias de la misma fecha: 10 de mayo de 2016 (número de resolución de 1035 a 1039, de 2016) en las que se sostienen los mismos argumentos para dar respuesta a los conflictos que plantearon cada unas las CCAA con la AGE y entre ellas, en relación con el reparto del déficit público. Cada Sentencia, redactada por distinto ponente, incluye ligeras variantes que no afectan a los argumentos ni, obviamente, al fallo. 
que el Gobierno debía remitir a las Cortes y el mencionado en el art. 16 LOEPSF, que concreta los objetivos de estabilidad presupuestaria y deuda pública para cada una de las CCAA. El TS inadmite los recursos para dos de los acuerdos recurridos aquellos que considera como una suerte de acto de trámite de un procedimiento cuya aprobación tiene lugar en sede parlamentaria (los del art. 15.1 LOEPSF, relativos a la aprobación del techo de gasto), desestima en otros dos casos y estima y declara nulo el Acuerdo del Consejo de Ministros que había concretado los objetivos para las CCAA (del art. 16 LOEPSF) por carecer de presupuesto habilitante, dado que el acto que pretendía desarrollar carecía de eficacia (en referencia al Acuerdo del Gobierno que acordaba el "techo de gasto", que el propio TS había considerado una suerte de acto de trámite sin efectos jurídicos por sí mismo) ${ }^{87}$.

El TS deja claro en estas Sentencias que la decisión que finalmente compete a las Cortes para fijar el techo de gasto "delimita el contenido de la potestad presupuestaria de las AAPP y demás sujetos comprendidos en el ámbito de aplicación de dicha Ley (en referencia a la LOEPSF), a los efectos de velar por la observancia de la disciplina presupuestaria". Entiende que "sostener que el acuerdo del Consejo de Ministros tiene sustantividad propia, no subordinada a la decisión parlamentaria, supondría desapoderar a las Cortes generales de una facultad que constitucionalmente les corresponde en exclusiva. Y si se afirma la jurisdicción de esta Sala para enjuiciar este acuerdo, no habría argumentos serios para rechazarla respecto de otros actos del Consejo de Ministros, como sería el caso del que apruebe el proyecto de Ley de presupuestos o cualquier proyecto de Ley, actuaciones éstas que, como hemos visto, la jurisprudencia considera ajenas al ámbito propio de esta Jurisdicción”. En la práctica esta doctrina jurisprudencial viene a concluir que el Acuerdo del Gobierno que propone a las Cortes los objetivos de techo de gasto entraría a formar parte de los llamados "actos de gobierno" -en la subcategoría de actos de relación entre el ejecutivo y el legislativo- ${ }^{88}$.

Este es un asunto de relevancia teórica que hasta la fecha ha pasado relativamente desapercibido. Pone en el centro del debate la vieja cuestión sobre el papel del poder legislativo en materia presupuestaria y control financiero sobre el ejecutivo.

En este sentido pueden además destacarse los siguientes aspectos:

a) Uno primero de carácter político, que tiene que ver con el papel del Senado, como ya ha sido apuntado.

${ }^{87}$ La expresión "acto de trámite" es mía. El TS dice que sería un acto "inserto en un procedimiento especial, [...] acto carente de autonomía", FJ 5 (STS de 10 de mayo de 2016, (núm. Resolución: 1036/2016), ponente José Manuel Bandrés Sánchez-Cruzat).

88 En su voto particular, Rodríguez-Zapata discrepa precisamente en este punto, con argumentos también razonables. Básicamente entiende que la aprobación del techo de gasto por las Cámaras no es manifestación del ejercicio de su potestad legislativa, sino de su función de control al Gobierno. Entiende que "la aprobación parlamentaria no sana los vicios de que pudieran adolecer los actos que ser aprueban”. Por su parte, Peces Morate, que firma otro voto particular, entiende que el Acuerdo del Consejo de Ministros previsto en el art. 15 LOEPySF y aquí recurrido debería de ser considerado como un "acto definitivo adoptado por un órgano manifiestamente incompetente y, por tanto, nulo de pleno derecho". 
No parece descabellada, en mi opinión, la atribución de un papel relevante al Senado, habida cuenta de la progresiva pérdida de presencia del legislador y en particular de la Cámara baja. Este papel reforzado del Senado parece, de inicio, tener su lógica en su función de cámara territorial y dado el complejo trasfondo que el techo de gasto tiene en relación con la financiación territorial y sus consecuencias. Los acontecimientos políticos de los últimos ańos, la inestabilidad política generada por el nuevo y más complejo arco parlamentario, ha visto esta opción como una complicación más y no como una herramienta que facilite el acuerdo y el consenso entre las fuerzas políticas. Será quizá que la falta de una cultura de acuerdos ha llevado al traste un modelo que, sobre el papel, parecía cargado de sentido común desde la perspectiva del equilibrio legislativo-ejecutivo y del reparto del poder territorial. Sin mencionar la oportunidad de dar contenido al Senado.

b) Desde una perspectiva doctrinal, en el caso de la fijación del techo del gasto por el Gobierno, nos encontramos ante un nuevo caso de "acto del Gobierno" (art. 2.1 LJCA) cuyo control ha quedado fuera del perímetro de la Jurisdicción ordinaria. Llegado el momento, será al TC a quien corresponderá el control del "techo de gasto" aprobado por las Cámaras, un control que en sus aspectos materiales remite ex constitutione al Derecho europeo, que por esta vía de remisión recepticia -en última instancia, disponible soberanamente por el constituyente- puede llegar a convertirse en parámetro de la constitucionalidad.

c) Desde una perspectiva económica, cabe señalar dos cuestiones.

La elaboración del presupuesto y, en general, la política presupuestaria plantean un serio problema de adaptación a la realidad. La fijación de los objetivos de estabilidad presupuestaria y deuda pública (techo de gasto) en un momento concreto implica la realización de una "foto", cuando la materialidad sobre la que se proyecta se comporta como una película. Es decir, es una visión estática de una realidad dinámica. En un mundo que, además, evoluciona a gran velocidad, donde la información macroeconómica acerca de las perspectivas y la evolución económica llega casi diariamente y -de forma oficial- trimestralmente, la principal herramienta de la política económica corre riesgo cierto de obsolescencia ${ }^{89}$. La estrategia y complementariedad con la política monetaria es, en este sentido, imprescindible debido, entre otras cosas, a su mayor flexibilidad.

Además y siguiendo con la metáfora, el techo de gasto no solo es un foto fija de una realidad en movimiento, es que ni siquiera es una fotografía; se parece más a un dibujo. Se parece más a una representación de la realidad, cuyo ajuste a la realidad representada resulta una tarea compleja. Dicho de otro modo, los datos macroeconómicos que explican la evolución de la situación económica, lo hacen en un momento fijo, siendo que aquella, la situación económica es dinámica. El IPC y el PIB son las

89 Basta con recordar la imagen de la economía española a comienzos de 2019 y en el momento actual. Los datos, pero sobre todo las expectativas, incluida la influencia de los factores externos (Brexit, evolución de la economía alemana, guerra comercial entre China y USA...) pintan hoy un panorama francamente distinto. 
macrovariables que dibujan -estiman-cuál va a ser esa situación económica en un futuro próximo inmediato. A partir de esa estimación se toman las decisiones que determinan el techo de gasto, el presupuesto, los ingresos, los gastos, y el endeudamiento público. A través de este mecanismo, la macroeconomía pasa a la política y de ahí, al derecho y a las decisiones administrativas concretas. La fragilidad de la macroeconomía como ciencia de predicción del futuro genera no pocas dudas. Con todo, eludir la información que la ciencia de la macroeconomía aporta es un riesgo que políticamente pocos se atreverán a asumir y, tras su constitucionalización, resulta ya imposible puesto que ha pasado a formar parte de su modelo económico.

\section{EL PRINCIPIO CONSTITUCIONAL DE ESTABILIDAD PRESUPUESTARIA TRAS LA COVID-19: UNA OCASIÓN PARA REFLEXIONAR SOBRE SU ALCANCE Y DIFICULTADES}

\subsection{La crisis de la COVID y sus efectos sobre el presupuesto}

En marzo de 2020, como ya se ha dicho, la realidad social, económica, política y jurídica a nivel mundial se ha visto completamente alterada con la llegada de la pandemia generada por la COVID-19 90.

La crisis de la COVID-19 no solo ha impactado de lleno en la vida y en la salud de todos nosotros, lo ha hecho también, y de modo muy profundo, en la marcha de la economía y, en consecuencia, en las cuentas públicas. El cumplimiento de las exigencias de estabilidad presupuestaria se ha visto, y se va a ver, fuertemente comprometido. La situación está condicionando, y aparentemente relegando, dicho cumplimiento tanto en Espańa como en el resto del mundo ${ }^{91}$.

Más allá de las cifras $^{92}$, la falta de una perspectiva temporal hace difícil prever qué va a ocurrir en el medio plazo con el cumplimiento de las obligaciones adquiridas en materia de política fiscal, ya sea desde la perspectiva constitucional como desde la perspectiva del compromiso europeo. La propia Unión Europea ha dado

90 El Gobierno español, en la Exposición de Motivos del Real Decreto-ley 25/2020, de 3 de julio, de medidas urgentes para apoyar la reactivación económica y el empleo, califica la crisis de la COVID-19 como "La magnitud del impacto de este shock exógeno sobre la economía no tiene precedentes en la historia reciente".

91 Recordemos las palabras de Kristalina Giorgieva, Directora Gerente del FMI, citadas en nota 14. Bien es cierto que este mensaje conviene leerlo en su totalidad. El consejo de gastar para afrontar las necesidades sanitarias que está generando la pandemia no significa que, llegado el momento, no habrán de adoptarse ajustes fiscales que permitan recuperar la senda de la estabilidad.

92 En concreto el porcentaje del volumen de deuda pública en función del PIB en el caso de España, en diciembre de 2019, rondaba el 95 por 100 y en marzo-abril de 2020 se situó en casi en el 99 por 100 , rompiendo la tendencia descendente que había iniciado la economía española desde 2014. Una magnífica fuente para acceder a este tipo de datos macroeconómicos es: https://datosmacro.expansion. $\mathrm{com} /$. 
pasos al frente para incrementar los gastos, mediante la creación de un fondo para la "reconstrucción" ${ }^{3}$. También a nivel interno, y una vez levantada la situación de alerta, desde el Gobierno se han puesto en marcha iniciativas de impulso económico de parecido tenor, aunque a la medida de la capacidad financiera de nuestras finanzas públicas $^{94}$.

Ciertamente esta extraordinaria situación, que ha impactado de lleno sobre la posición jurídica de ciudadanos y empresas -sus derechos y obligaciones, particularmente los derechos fundamentales como la libertad de desplazamiento, entre otros $^{95}$-, también lo ha hecho en las potestades y obligaciones de los poderes públicos desde el punto de vista de su compromiso presupuestario. En particular, y por no salirme del ámbito específico de este trabajo, la crisis del COVID-19 ha determinado hasta la fecha la aprobación de créditos extraordinarios ${ }^{96}$ y el recurso a la deuda para

93 "Reparar los daños y preparar el futuro": así es como la Comisión Europea ha titulado su propuesta hecha pública el 27 de mayo de 2020. Fue presentada como un "plan exhaustivo de recuperación", mediante la creación del Fondo Next Generation EU, véase la Comunicación The EU budget powering the recovery plan for Europe COM (2020) 442 final y en la Europe's moment: Repair and Prepare for the Next Generation COM (2020) 456 final. Al momento de cerrar estas líneas, los países miembros negocian las condiciones en que podrán acceder a esto fondos. Me atrevo a pronosticar que no será gratis.

94 Entre otras, el Real Decreto-ley 25/2020, de 3 de julio, de medidas urgentes para apoyar la reactivación económica y el empleo contempla precisamente un "Fondo de apoyo a la solvencia de empresas estratégicas", bajo la modalidad de fondo carente de personalidad jurídica, adscrito a la Administración General del Estado, a través del Ministerio de Hacienda. Este Fondo "tiene por objeto aportar apoyo público temporal para reforzar la solvencia empresarial, en particular mediante la concesión de préstamos participativos, deuda subordinada, suscripción de acciones u otros instrumentos de capital, a empresas no financieras, que atraviesen severas dificultades de carácter temporal a consecuencia de la pandemia de la COVID-19 y que sean consideradas estratégicas para el tejido productivo nacional o regional, entre otros motivos, por su sensible impacto social y económico, su relevancia para la seguridad, la salud de las personas, las infraestructuras, las comunicaciones o su contribución al buen funcionamiento de los mercados" (art. 2.2 RDL 25/2020, cit.). Junto con ello, se ha aprobado también una "Línea para la cobertura por cuenta del Estado de la financiación otorgada por entidades financieras supervisadas a empresas y autónomos con la finalidad principal de financiar inversiones", por un importe máximo de 40.000 millones de euros, hasta el 31 de diciembre de 2020 (art. 1 RDL 25/2020, cit.).

95 La respuesta jurídica a la crisis de la COVID-19, empezando por el propio recurso a la declaración del estado de alarma, ha dado lugar a multitud de reflexiones doctrinales de todo tipo, y por supuesto también desde el Derecho público. A modo de mero ejemplo, véase el número 86-87, de Cronista del Estado Social y Democrático de Derecho, Dedicado a: Coronavirus y otros problemas, de 2020 y los trabajos que ahí se publican. También el núm. 54 de la $R G D A$, de 2020, ha incluido una nueva sección, con cuatro estudios, específicamente dedicada a la COVID.

96 Las primeras concesiones de créditos extraordinarios para atajar la crisis de la COVID-19 estaban ya incluidas en el Real Decreto-ley 7/2020, de 12 de marzo, por el que se adoptan medidas urgentes para responder al impacto económico de la COVID-19: 1.000 millones de euros para el Ministerio de Sanidad (art. 1) y 25.000 millones euros para el Presupuesto del Ministerio de Derechos Sociales y Agenda 2030 para financiar los programas de servicios sociales de las Comunidades Autónomas, destinados a la partida presupuestaria correspondiente a: "Protección a la familia y atención a la pobreza infantil. Prestaciones básicas de servicios sociales". Con posterioridad, en los sucesivos Reales Decretos Leyes que han seguido a este primero dedicados a la crisis de la COVID-19 se han incluido nuevas autorizaciones a créditos extraordinarios. Es el caso, por ejemplo, de los 16.000 millones de euros del 
cubrir los nuevos gastos, de todo tipo, generados por la crisis, así como la aprobación de excepciones a las normas de contratación pública ${ }^{97}$ o la suspensión de los plazos administrativos $y$, en general, su impacto sobre el procedimiento administrativo ${ }^{98}$.

\subsection{La cláusula de excepción de la estabilidad presupuestaria}

Lo cierto es que tanto las normas europeas como la propia CE han previsto la existencia de situaciones extraordinarias que impidan de facto el cumplimiento de las obligaciones inherentes al principio de estabilidad presupuestaria.

En concreto, el art. 135.4 CE prevé que "[l] os límites de déficit estructural y de volumen de deuda pública solo podrán superarse en caso de catástrofes naturales, recesión económica o situaciones de emergencia extraordinaria que escapen al control del Estado y perjudiquen considerablemente la situación financiera o la sostenibilidad económica o social del Estado, apreciadas por la mayoría absoluta de los miembros del Congreso de los Diputados" 99 . En el caso de las normas europeas, es el art. 3 del TECG el que prevé la existencia de "circunstancias excepcionales" [art.3.1.c)], circunstancias que, en su caso permitirán a los países firmantes "desviarse temporalmente de su objetivo a medio plazo respectivo o de la senda de ajuste hacia dicho objetivo". Según la letra b) del art.3.3 se entiende por circunstancia excepcional "aquel acontecimiento inusual que esté fuera del control de la Parte Contratante afectada y tenga una gran incidencia en la situación financiera de las administraciones públicas o aquellos períodos de grave recesión económica a tenor del Pacto de Estabilidad y Crecimiento revisado, siempre que la desviación temporal de la Parte Contratante afectada no ponga en peligro la sostenibilidad presupuestaria a medio plazo". Con diferente lenguaje, en ambas normas se alude a circunstancias extraordinarias, excepcionales o inusuales; y en ambas aparece también la expresión recesión económica. No se trata de una mera situación excepcional, se trata de una situación

Real Decreto Ley 22/2020, de 16 de junio, por el que se regula la creación del Fondo COVID-19 y se establecen las reglas relativas a su distribución y libramiento.

${ }_{97}$ En materia de contratación pública han sido muchas y de distinta naturaleza las medidas acordadas por vía de urgencia. Así, por ejemplo, el art. 16 del RDL 7/2020, de 12 de marzo, por el que se adoptan medidas urgentes para responder al impacto económico del COVID-19, luego modificado por la DF 2 RDL 9/2020, de 27 de marzo para declarar la tramitación de emergencia de ciertos contratos; o la modificación el art. 159.4 LCSP, en virtud de la DF 3 del RDL 16/2020, de 28 de abril. Sobre el particular, véase José María GIMENO FELIÚ, "La crisis sanitaria COViD-19 y su incidencia en la contratación pública”, El Cronista del Estado Social y Democrático de Derecho, dedicado a: Coronavirus y otros problemas, núm. 86-87, 2020, pp. 42-53.

${ }_{98} \mathrm{Al}$ respecto, véase Vicente ÁLVAREZ GARCÍA y Flor ARIAS APARICIO, "La incidencia del derecho de necesidad en el procedimiento administrativo: la alteración de las reglas procedimentales por motivos de necesidad", RGDA, núm. 54, 2020.

$99 \mathrm{El}$ art. 11 del LOEPSF desarrolla este precepto añadiendo al supuesto de hecho una limitación que no está en la Constitución, y que la "desviación temporal no puede poner en peligro la sostenibilidad fiscal a medio plazo". 
excepcional que impacte sobre la marcha de la economía hasta el punto de generar una recesión económica.

Hasta la fecha, la excepcionalidad de la crisis de la COVID-19 no ha llevado, en el caso español, a activar formalmente el procedimiento parlamentario previsto en el art. 135.4 in fine, que exige la apreciación de la situación por mayoría absoluta del Congreso de los Diputados. Por cierto que poco más aclara la Constitución. Nada se dice sobre quién debe pedirlo ni sobre el cómo. Se entiende que corresponderá al Gobierno puesto que es quien debe iniciar el procedimiento parlamentario para la aprobación, primero del techo de gasto y después de los Presupuestos y es, en definitiva, destinatario de este precepto. Tampoco se dice nada acerca de cuándo debe o puede pedirse. En este caso, pienso que también puede defenderse la idea de que debería pedirse antes de la aprobación del techo de gasto, puesto que, en definitiva, lo determina ${ }^{100}$. En las circunstancias actuales, podría incluso plantearse si las sucesivas autorizaciones de las posteriores ampliaciones del estado de alarma -en algún caso con mayoría absoluta- implican de facto un reconocimiento por parte del Congreso de los Diputados de una situación inusual o de una situación de emergencia extraordinaria que escape al control del Estado, situación que avala el desplazamiento circunstancial de las exigencias de la disciplina presupuestaria.

La activación de la cláusula de excepción no implica el incumplimiento de las previsiones constitucionales, antes bien es una manifestación de su carácter normativo.

Volviendo al caso planteado, según pasen los meses y la situación sanitaria llegue a estabilizarse, la preocupación por los aspectos económicos de la crisis se recrudecerán y la evolución de las finanzas públicas, sin duda tomará todo el protagonismo. La crisis de la COVID-19 supone un ejercicio de resistencia del modelo macroeconómico que subyace en la Constitución que tiene, como elemento determinante, la necesaria estabilidad económica. El cumplimiento de la norma constitucional se muestra especialmente sensible a la propia evolución de la economía. Ello plantea, a mi juicio, un elemento de fragilidad del modelo de juridificación de la macroeconomía, en la medida en que su estricto cumplimiento se torne casi imposible. A no ser que lo que realmente se pretenda sea un objetivo de estabilidad presupuestaria en sentido tendencial o con carácter principial.

En mi opinión, un modelo constitucional que aluda al límite de la sostenibilidad -entendida como estabilidad sostenida y con impacto intergeneracional- resultaría más creíble. En primer lugar por su mayor vinculación al principio democrático, así como la lógica de la restricción de no gastar lo que no se tiene. También porque reforzaría la responsabilidad para con nuestro propio desenvolvimiento como país frente a una posición de país "tutelado" por las instancias europeas.

100 También podría argumentarse que una propuesta de techo de gasto presentada al Congreso y al Senado, cuya cifra se desviase del objetivo de estabilidad presupuestaria, podría justificarse precisamente en alguna de las causas del art. 135.4, permitiendo así -indirectamente- la aprobación de la existencia de la causa. 


\subsection{Dificultades para la estabilidad presupuestaria y, en particular, para su cumplimiento en situaciones de excepción}

La opción por "constitucionalizar", en definitiva someter a derecho, las decisiones de los poderes públicos con impacto macreconómico, manifiesta sus claroscuros, precisamente, con ocasión de la crisis. La dirección de la economía por parte de los poderes públicos se ha mostrado en todo momento y hasta la fecha $-\mathrm{y}$ no solo con ocasión de esta reciente crisis- como un ejercicio de ajuste fino. Someter a reglas excesivamente rígidas estas decisiones suscita muchos interrogantes y dificultades, y obliga a reflexionar sobre el papel correlativo del derecho, en particular del Derecho público, sobre la economía y viceversa.

La primera de las dificultades tiene que ver con la evolución y el comportamiento de las variables económicas que aportan información acerca de la marcha de la economía de un país o región -o en su caso, grupo de países, como la Unión Europea-. Conviene recordar que su comportamiento no es solo, ni mucho menos, resultado de decisiones de los poderes públicos, por más que éstas sean determinantes. El devenir de lo económico y su impacto en el bienestar y en el progreso social es resultado de múltiples factores, una parte importante de ellos ajenos al poder político, como he querido apuntar cuando me he referido a la economía como un sistema abierto. La crisis de la COVID-19 ofrece un perfecto ejemplo. En este contexto, y en el bien entendido que los poderes públicos trabajan para lograr un mejor y mayor progreso económico y social, así como la estabilidad económica, ¿qué opción es preferible? ¿La fijación de reglas fiscales rígidas y densamente determinadas y predecibles? ¿O la atribución de un margen de maniobra suficiente y necesario en el marco de unos objetivos que faculte al poder político-económico de capacidad para adaptarse a la evolución del entorno? Nuestra norma constitucional y la LOEPSF, así como el Derecho europeo, parece que han optado por la primera. El resultado de esta opción es un modelo aparentemente rígido aunque quizá más seguro, previsible y estable a medio plazo.

A esta dificultad se une, como es bien sabido, el desfase temporal que implica la "medición" de lo económico. Los presupuestos se diseñan y ejecutan, en el mejor de los casos, en el marco temporal de una anualidad, mientras que la evolución de la economía se mide por trimestres, cuando no por meses. Si, desde el análisis de los datos económicos, dos trimestres consecutivos de decrecimiento se consideran recesión económica, y estos tienen lugar, por ejemplo, en el primer y segundo trimestre del año, la eficacia de las medidas fiscales y presupuestarias adecuadas (por ejemplo, tributarias), en el mejor de los casos, tardarán casi un año en llegar. Este desfase temporal entre la evolución de la economía y las grandes decisiones de política fiscal y presupuestaria ha sido tradicionalmente uno de los argumentos a favor del uso de la política monetaria como herramienta de estabilidad económica y no solo como mera función de protección del nivel de precios y del valor de la moneda. En este sentido, la política monetaria ofrece soluciones ad hoc que permiten llevar a cabo ajustes en la 
economía de modo más rápido y eficaz ${ }^{101}$ ante situaciones de inestabilidad, recesiones o, al contrario, de "recalentamiento" de los precios. Sin embargo, en el contexto del euro, el recurso a los instrumentos de política monetaria presenta no pocas dificultades. La primera de ellas está relacionada con el hecho de que la evolución de la economía de los distintos países de la eurozona manifiesta diferencias no pequeñas, como de hecho ocurre en el momento actual en relación con la respuesta que cada Estado ha adoptado ante la COVID-19 y el impacto en sus economías. Tampoco ayudan las políticas monetarias de bajos tipos de interés que, desde años, practican el BCE o la Reserva Federal y que dejan poco -o ningún- margen de maniobra. $\mathrm{Y}$, en tercer lugar y más importante desde el punto de vista jurídico, el principal escollo radica en el propio diseño institucional del BCE como autoridad monetaria independiente y en las funciones que tiene atribuidas - proteger la estabilidad de la moneda y de nivel de precios en la eurozona ${ }^{102}$ y no, al menos en teoría, otro tipo de objetivos ${ }^{103}$.

La tercera dificultad que plantea el cumplimiento del régimen de estabilidad presupuestaria previsto en la CE tiene que ver con la complejidad que supone la propia medición y cálculo de las macrovariables que la $\mathrm{CE}$ ha juridificado, empezando por el PIB. Hay que tener en presente que cuando hablamos de cuantificar el PIB nos estamos refiriendo tanto a una cuantificación real y necesariamente a posteriori como a una previsión estimada de su evolución futura. No será el mismo el dato del PIB que se toma como referencia para el diseńo de los presupuestos y la aprobación del techo de gasto -obviamente, una estimación- que el PIB que se toma en consideración para activar la cláusula de excepción en caso de recesión económica que se mide sobre datos reales y, como digo, a posteriori. No hay que perder de vista que la cuantificación del PIB es uno de los principales problemas que se le ha planteado a la ciencia económica, tanto cuando intenta explicar lo ocurrido como cuando intenta adivinar qué ocurrirá.

101 Recordemos la eficacia de unas pocas palabras. Bastó que Draghi afirmara que haría lo necesario -es decir, que el BCE haría lo necesario- para responder a la crisis para tranquilizar a los mercados internacionales de deuda y la tensión vivida por el euro.

102 Véase, por todos, Jorge GARCÍA-ANDRADE GÓMEZ, "El sistema monetario en una Unión Europea ...", op. cit., pp. 151-320. También, José Luis MARTÍNEZ LÓPEZ-MUNIZ, "Problemas de cobertura jurídica de la supervisión bancaria del BCE en la nueva unión bancaria y apuntes para su solución", Revista de Estudios Europeo, núm. 63, 2013, pp. 79-114.

103 Aquí radica precisamente el problema de fondo que ha dado lugar a la STC alemán contra el BCE y sus operaciones de compra de bonos. Entendían los recurrentes, y así lo ha aceptado el tribunal que el BCE habría sobrepasado su mandato estatutario. La política monetaria del BCE, capitaneada por Mario Draghi durante la Gran Crisis financiera, puso en marcha planes de compra de bonos que permitieron bajar la tensión en los mercados de deuda pública, controlando de ese modo el tipo de interés pagado por los Estados y el coste de su financiación, eliminando tensiones en el sistema económico de los Estados miembros en situación de fragilidad; en particular, Italia y España. Sobre esta sentencia y el problema de fondo, véase José Eugenio SORIANO GARCÍA, "Deutschland über alles: una canción entonada por el Tribunal Constitucional alemán que invade Europa”, en LA LEY Unión Europea, núm. 82, 2020, Wolters Kluwer. 
El papel que tienen las estimaciones para la toma de decisiones en materia presupuestaria es crucial para la fijación de las cuantías ¿Cuánto crecerá o decrecerá el PIB en el año entrante? ¿A cuánto alcanzará la recaudación tributaria que depende del PIB? ¿A cuánto, en definitiva, alcanzará el techo de gasto? Centros de estudio, públicos y privados, nacionales e internacionales ${ }^{104}$, proveen de información y previsiones sobre la evolución del PIB, en ocasiones contradictorias, sobre la base de modelos matemáticos y de estimaciones ${ }^{105}$. No olvidemos que, en definitiva, este es el factum a partir del cual se toman las decisiones de política económica con fundamento macroeconómico, ahora sometidas al Derecho público.

\section{ALGUNAS REFLEXIONES CONCLUSIVAS}

Desde la perspectiva de la macroeconomía, en nuestro modelo económico constitucional y en la medida en que la opción de acudir a la política monetaria se encuentra restringida, los ajustes de política económica pasan necesariamente por la política fiscal y presupuestaria y por las reformas estructurales que permiten incidir en algunos de los costes de producción para hacerlos más o menos competitivos. Significativamente forman parte de estas reformas aquellas que inciden sobre el empleo y la legislación laboral ${ }^{106}$, así como ciertas medidas liberalizadoras que permiten el abaratamiento -o en su caso, encarecimiento- de algunos bienes y servicios. Dejando al margen este último factor, que abre una compleja gama de problemas jurídicoeconómicos, y también políticos, que desbordaría los límites de esta reflexión, la "juridificación” de la estabilidad presupuestaria supone la introducción al máximo nivel normativo de límites cuantitativos a las posibles opciones de política fiscal, estrechando el margen de discrecionalidad política y económica. Puede decirse que la Constitución ha puesto cifra al principio operativo de "nadie puede gastar más lo que tiene", en concreto incorporando el modelo del TFUE, en cuyo Protocolo 12 se fija en el 60 por 100 el volumen total de deuda púbica en relación con el PIB y en el 3 por 100 el déficit público en relación con dicho PIB.

La pregunta que surge es: ¿y por qué estos límites y no otros? ¿Qué criterios técnicos o de razonabilidad avalan esta concreta opción? Lo cierto es que, al menos en el caso de España, aún estamos lejos de cumplir con estos límites cuantitativos, más después de la crisis de la COVID-19 y la recesión económica abierta. Constatar que una norma constitucional tan concreta resulta de difícil o imposible cumplimiento,

104 Son muchas las instituciones - públicas y privadas- que se dedican al análisis de datos económicos, que elaboran informes y opiniones acerca del comportamiento -pasado y futuro- de la economía: el FMI, el BE, el BCE, las agencias públicas de información estadísticas, el Servicio de Estudios del BBVA y de otros tantos bancos nacionales e internacionales, empresas de consultoría, entre otros.

105 No puedo evitar recordar en este punto a mi profesor de economía, Miguel Alfonso MartínezEcheverría, en sus primeras clases, En particular su reflexión sobre la capacidad de estimación de la macroeconomía, según la cual su capacidad de acierto se parecía a la de un cazador tuerto que caza palomas en vuelo con una escopeta con la mira descentrada.

106 Es el caso de las normas laborales que determinan el coste del despido. 
es altamente ineficaz tanto desde el punto de vista jurídico como económico, además de plantear fuertes tensiones políticas. Si a ello se une la inestabilidad política, que hace que sigamos con los mismos presupuestos por tercer año consecutivo, la norma constitucional corre el riesgo de perder la auctoritas que la hace creíble y eficaz.

$\mathrm{Al}$ imponerse un modelo que somete a normas de Derecho público la política económica, en concreto ciertas decisiones de los poderes públicos con relevancia macroeconómica como son la determinación del nivel de gasto público y el nivel máximo de endeudamiento, el margen de decisión política -y la actual situación de crisis generada por la COVID-19 así lo pone de manifiesto- se reduce y condiciona drásticamente. Por otra parte, hay que considerar que en realidad, este sometimiento a derecho y su control es operativo en el ámbito europeo, donde se han previsto los procedimientos de déficit excesivo para aquellos países que incumplan los compromisos de estabilidad presupuestaria y, en su caso, las vías de legitimación jurisdiccional necesarias para que el TJUE pueda revisar la corrección de estos controles que la UE lleva a cabo ${ }^{107}$.

En situaciones de fuerte caída del PIB la evolución de resto de variables se verá condicionada tanto por su impacto en la recaudación vía impuestos como por la necesidad de aumentar los gastos y auxilios sociales. Este desequilibrio solo podrá financiarse con deuda pública.

Si el alcance del déficit público está normativamente limitado y el volumen de deuda también, las opciones son pocas: subir impuestos, bajar gastos... o los dos. Ninguna de estas opciones es oportuna para resolver el desequilibrio generado por la crisis. El funcionamiento sistémico de la economía, del que hablaba al comienzo de estas páginas, apunta a que cualquiera de estas recetas, en el corto plazo, agravaría la situación y no al contrario. Si aumenta la presión fiscal habrá menos recursos disponibles para dedicarlos a la inversión, ahondando en el círculo vicioso de la recesión. Y, si se reduce el gasto público se resentirán los mecanismos de solidaridad social en el momento en que es más necesario, tanto desde un punto de vista humanitario y de los derechos fundamentales como incluso desde a perspectiva económica, en la medida en que estos mecanismos se comportan como estabilizadores automáticos de la economía ${ }^{108}$.

107 Véase Tomás DE LA QUADRA-SALCEDO JANINI, "La discrecionalidad política del ECOFIN en la aplicación del procedimiento por déficit excesivo. Reflexión tras la Sentencia del Tribunal de Justicia de 13 de junio de 2004”, REP (Nueva Época), núm. 176, 2004, pp. 151-176. En el caso de España, nuestro país ha estado sometido desde 2009 hasta mediados de 2019 a la tutela y control derivada de la situación déficit excesivo por parte de la Comisión Europea, al igual por cierto que la práctica totalidad de los Estados miembros, que en algún momento han pasado también por este procedimiento.

108 Así, los fondos públicos destinados al subsidio de desempleo o, incluso, el más reciente Ingreso Mínimo Vital, aprobado por el RDL 20/2020, de 29 de mayo, tienen un incidencia desde el punto de vista económico positiva en la medida en que "regresan" al presupuesto público dado que generan una cierta actividad económica y, al menos, minimizan su estancamiento.

Los estabilizadores automáticos "son medidas que estimulan o deprimen la economía en el momento necesario sin necesidad de introducir cambios deliberados en la política económica. Por ejemplo, el impuesto sobre la renta recauda automáticamente menos impuestos cuando la economía entra en una 
En materia de política económica y fiscal, los Gobiernos se encuentran siempre, especialmente en tiempos de recesión pero también en épocas de bonanza, ante dilemas cuya solución vendrá condicionada por los planteamientos ideológicos de cada momento, pero teniendo que elegir con un margen de decisión cada vez menor. Esta situación es particularmente acentuada en la eurozona, allí donde ha desaparecido la política monetaria nacional (centralizada en manos del BCE) y el pacto de estabilidad y crecimiento, en su día acordado, ha restringido las opciones de política fiscal fijando un concreto compromiso de estabilidad presupuestaria (el del Protocolo 12, del TFUE) ${ }^{109}$. Pero no los países de la eurozona no son los únicos. El dilema se le presenta a cualquier economía mundial que necesite financiarse en los mercados internacionales de deuda. En definitiva, estamos hablando de la solvencia que como acreedor presenta cada país y, al igual que ocurre con los deudores privados, los mercados valoran al buen gestor, que garantiza la devolución del préstamo y el pago del interés y castigan al manirroto, al que gasta por encima de lo que tiene o puede generar.

La crisis de la COVID-19 va a permitirnos observar el alcance de los compromisos europeos y de la "juridificación" de la estabilidad presupuestaria en un contexto de fuerte recesión. La válvula de presión del art. 135.4 CE todavía no se ha activado formalmente. El peso de las instituciones europeas encargadas de controlar el techo de gasto que las Cortes han de aprobar, como primera fase para la tramitación de los nuevos presupuestos, va a resultar determinante como muestra de la profunda integración de los países de la eurozona.

La política, el derecho y la economía resultan inescindibles en materia presupuestaria. La aprobación de la Ley de Presupuestos se presenta como el momento central del curso político y parlamentario y la ocasión para comprobar el alcance del papel que el derecho ha otorgado realmente a la macroeconomía. Es mucho más que un trámite de buena administración y gestión eficiente y de control político. Es el momento clave del Estado social y democrático ${ }^{110}$. Por otra parte permite tomar el pulso al grado de soberanía democrática ${ }^{111}$ representada en el Parlamento, en la medida

recesión, sin necesidad de modificar la legislación tributaria, ya que los individuos y las empresas pagan menos impuestos cuando su renta disminuye. Asimismo, el seguro de desempleo y los programas de asistencia social aumentan automáticamente las transferencias cuando la economía entra en una recesión porque aumenta el número de personas que tienen derecho a estas prestaciones", véase Gregory MANKIW, Macroeconomía, 8.a ed., Trad. Esther RABASA, Bosch, Barcelona, 2014, p. 710.

$109 \mathrm{Al}$ momento de cerrarse este trabajo llegan noticias del histórico pacto que han alcanzado los líderes europeos para la creación de un fondo de 750 mil millones de euros -entre transferencias a fondo perdido y créditos- para la reconstrucción y salvamento de las economías europeas más afectadas por la Crisis COVID-19. Habrá ocasión de analizar tan histórico acuerdo, así como las herramientas jurídicas y económicas a través de las que se va a arbitrar. La principal novedad es, sin duda, la financiación de dicho fondo vía deuda pública siendo su emisora la propia UE, lo que por primera vez implica una mutualización de los riesgos con garantía de la propia UE.

110 Por ello la anomalía de unos presupuestos ampliados por más de dos años suscita dudas no pequeńas de legitimidad -que no de legalidad- de un Gobierno que no es capaz de sacar adelante su propio proyecto político y económico.

111 Precisamente afirmar que la soberanía es graduable implica ya un claro contrasentido. Me remito en este punto a la nota 68 supra y a la mención ahí expuesta sobre el concepto jurídico de soberanía. 
en que aprueba unas cuentas cuyas determinaciones principales (macroeconómicas) vienen fijadas por la UE. Dejando a un lado el espinoso asunto sobre el concepto político-jurídico de soberanía, en el que no voy a entrar, sí quiero insistir en la idea de que la cesión de una parte de la soberanía - la monetaria, con la creación del euro- ha actuado como factor de arrastre de otras manifestaciones de la soberanía ${ }^{112}$. O dicho de otro modo, del alcance del principio democrático a la hora de determinar la política económica, manifestado en la política presupuestaria. Desde la teoría económica este efecto sin duda se explica debido al comportamiento sistémico de la economía, que apuntaba al comienzo de este trabajo, así como a la estructural restricción del gasto.

\section{BIBLIOGRAFÍA}

Enoch ALBERTÍ ROVIRA, "La constitución económica de 1978. (Reflexiones sobre la proyección de la Constitución sobre la economía en el XXV Aniversario de la Constitución española)", $R E D C$, núm. 71, 2004, pp. 123-159.

Alberto ALONSO UREBA, La empresa pública. Aspectos jurídico-constitucionales y de derecho económico, Montecorvo, Madrid, 1985.

Vicente ÁLVAREZ GARCÍA y Flor ARIAS APARICIO, "La incidencia del derecho de necesidad en el procedimiento administrativo: la alteración de las reglas procedimentales por motivos de necesidad”, $R G D A$, núm. 54, 2020.

Manuel ARAGÓN REYES, Libertades económicas y estado social, McGraw-Hill Madrid, 1995.

Gaspar ARIÑO ORTIZ, Principios de Derecho Público económico. Modelo de Estado, Gestión Pública, Regulación económica, Marcial Pons/Idelco, Madrid, 1999.

Antonio ARROYO GIL, "La reforma constitucional de 2009 de las relaciones financieras entre la Federación y los Länder en la República Federal de Alemania", Revista d'Estudis Autonòmics i Federals, núm. 10, 2010, pp. 40-71.

- "La cláusula de estabilidad presupuetaria: tras la senda constitucional alemana", Cuadernos Manuel Giménez Abad , núm. 6, 2013, pp. 39-47.

Luis ARROYO JIMÉNEZ, Libre empresa y titulos habilitantes, CEPC, Madrid, 2004.

Martín BASSOLS COMA, "La planificación", en Fernando GARRIDO FALLA, El modelo económico en la Constitución Español, IEE, Madrid, 1981.

— "La Constitución económica”, RDP, núm. 366, 1992, pp. 277-290

— "La reforma del artículo 135 de al Constitución espańola y la constitucionalización de la estabilidad presupuestaria: el proceso parlamentario de elaboración de la reforma constitucional”, $R E D A$, núm. 2-155, 2012, pp. 21-41.

— "La crisis económica y sus repercusiones en el Derecho Público; el Principio de Buena Regulación Económica, supresión de cargas administrativas y constitucionalización de la estabilidad presupuestaria" Noticias de la Unión Europea, núm. 325, 2012, pp. 3-15.

112 También para Susana RUIZ TARRÍAS "sin que exista constancia de cómo y en qué momento los Estados de la UE han realizado una cesión en el ejercicio de sus competencias soberanas en materia presupuestaria a las instituciones europeas, en tanto que no se ha producido una modificación expresa en este sentido en el Derecho originario, la intervención de éstas últimas en el procedimiento presupuestario nacional conduce a una modificación de la fisonomía del concreto sistema de gobierno de cada Estado de la eurozona, cuyos órganos constitucionales y sus respectivas competencias aparecen condicionadas por decisiones adoptadas por instancias supraestatales", véase Las dimensiones constitucionales de la Unión Económica y Monetaria Europea, Civitas Thomson Reuters, Pamplona 2016, p. 254. 
Marc CARRILLO, "Constitución y control de las finanzas públicas", REDC, núm. 101, 2014, p. 2426.

James M. BUCHANAM, "Clarifying Confusion about the Balanced Budget Amendment", National Tax Juournal, 1995, núm. 48 (3), pp. 347-350.

- "Concerning Future Generations", en J. M. FERGUSON (ed.) Public Debt and Future Generations, University of North Carolina Press, 1964.

Juan CALVO VÉRGEZ, "La creación de la nueva autoridad independiente de responsabilidad fiscal en torno al alcance de sus informes y opiniones”, Revista Aranzadi Doctrinal, núm. 11(marzo), 2014, pp. 61-75.

Francisco Jesús CARRERA HERNÁNDEZ, "El Tratado de Estabilidad, Coordinación y Gobernanza en la Unión Económica y Monetaria: ¿̇un impulso a la realización de la Política Económica de la Unión Europea o un tratado superfluo e innecesario?”, RGDE, núm. 28, 2012.

Carlo Alberto CIARALLI, "Límites del principio de estabilidad presupuestaria respecto de la autonomía financiera de las Comunidades Autónomas españolas", REALA Nueva Época, núm. 9, (2018), pp. 60-83.

Antonio CIDONCHA, La libertad de empresa, Thomson/Civitas, Cizur Menor (Navarra), 2006.

Francisco COMÍN COMÍN, La crisis de la deuda soberana en España (1500-2015), Los Libros de la Catarata, D.L., Madrid, 2016.

Matilde CUENA CASAS, "Intercambio de información positiva de solvencia y funcionamiento el mercado de crédito", InDret, 3/2017.

M. Mercè DARNACULLETA I GARDELLA, "Conseqüències institucionals de la limitació del deute públic a les comunitats autònomes i als Länder. Una anàlisi comparada dels mecanismes de control de l'estabilitat pressupostària a Espanya i Alemanya”, Revista d'estudis autonòmics i federals núm. 20, 2014, pp. 74-213.

Kevin. E. DAVIS, Angelina FISHER, Benedict KINGSBURY y Sally E. MERRY, Governance by Indicators. Global Power through Quantification and Rankings, Oxford University Press, 2012.

Fernando DE LA HUCHA CELADOR, "La reforma del artículo 135 de la Constitución: estabilidad presupuestaria y deuda pública", $R E D F$, núm. 153, 2012, pp. 21-48.

- "Artículo 135 CE: Estabilidad presupuestaria y deuda pública", Tribuna en Diario La Ley, 14 de diciembre de 2018.

Tomás DE LA QUADRA-SALCEDO JANINI, "La discrecionalidad política del ECOFIN en la aplicación del procedimiento por déficit excesivo. Reflexión tras la Sentencia del Tribunal de Justicia de 13 de junio de 2004”, REP (Nueva Época), núm. 176, 2004, pp. 151-176.

- "La incidencia de la reforma del artículo 135 de la Constitución sobre el Estado autonómico", Informe sobre Comunidades Autónomas, 2016, pp. 77-110.

Josu DE MIGUEL BÁRCENA, "Estabilidad financiera en entornos federales: la nueva Constitución económica del riesgo", Revista de Derecho Constitucional Europeo, núm. 26, julio-diciembre, 2016.

- "La recepción constitucional de la cláusula de estabilidad presupuestaria en Italia. Comentario a las Sentencias 10/2015 y 70/2015 de la Corte Constitucional”, Revista Española de Derecho Constitucional, núm. 106, 2016, pp. 431-449.

- Antonio EMBID IRUJO, La constitucionalización de la crisis económica, Iustel, Madrid, 2012.

- José ESTEVE PARDO, "La regulación de la economía desde el Estado garante", en Publicaciones de la Asociación Española de Profesores de Derecho Administrativo, Thomson-Aranzadi, Pamplona, 2007, pp. 79 y ss.

- María Luisa ESTEVE PARDO, "El impacto del principio de estabilidad presupuestaria sobre los Gobiernos locales", en Anuario del Gobierno Local, núm. 1, 2012, número dedicado a "Racionalización y sostenibilidad de la Administración local: jes esta la reforma?", pp. 153-172

- German FERNÁNDEZ FARRERES, "Reflexiones sobre el principio de subsidiariedad y la administración económica", en Estudios de derecho público económico: libro homenaje al prof. Dr. D. Sebastián Martín-Retortillo, Civitas, Madrid, 2003, pp. 165-184.

- Tomás-Ramón FERNÁNDEZ, "Reflexiones sobre a la sostenibilidad de los servicios públicos", RAP, núm. 200, 2016, pp. 439-450. 
Juan Ignacio FONT GALÁN, "Notas sobre el modelo económico de la Constitución española de 1978”, RDM, núm. 152, 1979, pp. 205-239

Tomás FONT LLOVET y Alfredo GALÁN GALÁN, "La reordenación de las competencias municipales ¿̨una mutación constitucional?”, Anuario del Gobierno Local 2013, 2014, pp. 8-9

José GARCÍA ALCORTA, La limitación de la libertad de empresa en la competencia, Atelier, Barcelona, 2008.

Manuel GARCÍA PELAYO, "Consideraciones sobre la cláusulas económicas de la Constitución”, en Manuel RAMÍREZ, Estudios sobre la Constitución Española de 1978, Pórtico, Zaragoza, 1979, pp. 27 y ss.

Javier GARCÍA ROCA y Miguel Ángel MARTÍNEZ LAGO, Estabilidad presupuestaria y consagración del freno constitucional al endeudamiento, Civitas-Thomson Reuters, Cizur Mayor, 2013.

— "La repentina constitucionalidad de la Ley de Estabilidad presupuestaria según la STC 215/2014, de 18 de diciembre", REDE, núm. 54, 2015, pp. 89-122.

Jorge GARCÍA-ANDRADE GÓMEZ, "El sistema monetario en una Unión Europea de Derecho", en María Amparo SALVADOR ARMENDÁRIZ (dir.), Regulación bancaria: transformaciones y Estado de derecho, 2014, Cizur Menor (Navarra), pp. 151-320.

- "La aplicación del principio constitucional de estabilidad presupuestaria a las entidades locales", en Luis COSCULLUELA MONTANER, Luis MEDINA ALCOZ (dirs.) y María HERNANDO RYDINGS (coord.), Crisis económica y Reforma del Régimen Local, Civitas-Thomson Reuters, Cizur Menor, 2012, pp. 293-327.

— "La cuestión prejudicial del Tribunal Constitucional alemán sobre la decisión OMT", Revista Española de Derecho Europeo, núm. 51, 2014, pp. 119-163.

— "La reforma del artículo 135 de la Constitución Española", RAP, núm. 187, 2012, pp. 31-66.

— "La garantía del Estado frente a la crisis económica", RAP, núm. 201, 2016, p. 101-129.

Pía GARCÍA-ESCUDERO MÁRQUEZ, "La acelerada tramitación parlamentaria de la reforma del art. 135 de la Constitución", en Teoría y Realidad Constitucional, núm. 29, 2012, pp. 433-452.

Fernando GARRIDO FALLA, El modelo económico en la Constitución Español, IEE, Madrid, 1981.

José María GIMENO FELIÚ, "Sistema económico y derecho a la libertad de empresa versus reservas al sector público de actividades económicas", RAP, núm. 135, 1994, pp. 149-212.

- "La crisis sanitaria COViD-19 y su incidencia en la contratación pública", El Cronista del Estado Social y Democrático de Derecho. Dedicado a: Coronavirus y otros problemas, núm. 86-87, 2020, pp. 42-53.

Charles GOODHART, The Evolution of Central Bank, Londres, 1988.

Friedrich HAYEK, La desnacionalización del dinero, traducción de C. LIAÑO, Instituto de Economía de Mercado Unión Editorial SA, Barcelona, 1983.

Charles P. KINDLEBERGER y Robert Z. ALIBER, Manias, pánicos y cracs: historia de las crisis financieras, traducción de B. RIBERA DE MADARIAGA, Ariel, Barcelona, 1991.

Rosa María LASTRA, International Financial and Monetary Law, 2. a ed., Oxford University Press, Oxford, 2015.

Juan Fernando LÓPEZ AGUILAR, "De la Constitución "irreformable" a la reforma constitucional 'exprés”, en Teoría y Realidad Constitucional, núm. 29, 2012, pp. 199 y ss.

Gregory MANKIW M., Macroeconomía, 8aed., Trad. RABASA, Esther, ed. Bosch, Barcelona, 2014.

Esther MARCO PEÑAS, "Delimitación del sector público y estabilidad presupuestario", Anuario de Derecho Municipal, núm. 12, 2019, pp. 219-243.

Antonio MARTÍ DEL MORAL, "La constitucionalización del principio de establidad presupuestaria", en Luis COSCULLUELA MONTANER, Luis MEDINA ALCOZ (dirs.) y María HERNANDO RYDINGS (coord.), Crisis económica y Reforma del Régimen Local, Civitas-Thomson Reuters, Cizur Menor, 2012, pp. 271-291.

Sebastián MARTÍN-RETORTILLO, Crédito, banca y Cajas de Ahorro. Aspectos juridico-administrativos, ed. Tecnos, Madrid, 1975.

— "Sistema bancario y crediticio", en Sebastián MARTÍN-RETORTILLO (coord.), Derecho Administrativo económico (vol. II), La Ley, Madrid, 1991, 39-278.

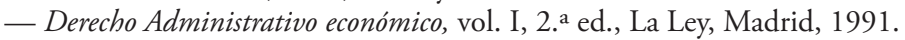


Miguel Ángel MARTÍNEZ LAGO, "Constitucionalización del principio de estabilidad presupuestaria en la Unión Europea y en España. La Ley Orgánica de Estabilidad Presupuestaria y Sostenibilidad Financiera", en Diego LÓPEZ GARRIDO (dir.) y M.a Luz MARTÍNEZ ALARCÓN (coord.), Reforma constitucional y estabilidad presupuestaria. El art. 135 del Constitución española, CEPC, Madrid, 2013, pp. 131-171.

- "Reglas fiscales y organismos independientes de supervisión: la Autoridad de responsabilidad fiscal española”, en Francisco David ADAME MARTÍNEZ Y Jesús RAMOS PRIETO (coords.), Estudios sobre el sistema tributario actual y la situación financiero del sector público: homenaje al Profesor Dr. D. Javier Lasarte Álvarez, Ministerio de Hacienda e IEF, Madrid, 2014, pp. 61-75 .

José Luis MARTÍNEZ LÓPEZ-MUNIIZ, Introducción al Derecho administrativo, Tecnos, Madrid, 1986.

— "La publicatio de recursos y servicios", en Estudios de derecho público económico: libro homenaje al prof. Dr. D. Sebastián Martin-Retortillo, Civitas, Madrid, 2003, pp. 687-718.

- "Problemas de cobertura jurídica de la supervisión bancaria del BCE en la nueva unión bancaria y apuntes para su solución", Revista de Estudios Europeo, núm. 63, 2013, pp. 79-114.

— "Persistencia en la UE actual del fecundo proyecto originario", en Guillermo PÉREZ SÁNCHEZ (dir.) y María Belén MIRANDA ESCOLA y Begońa VIDAL FERNÁNDEZ (coords.), La EU al cumplirse 90 años de la Declaración de Schuman, 1950-2020, Universidad de Valladolid, Valladolid, 2020, pp. 245-268.

Manuel MEDINA GUERRERO, "La constitucionalización de la regla del equilibrio presupuestario: integración europea, centralización estatal”, Revista de Estudios Políticos, núm. 165, 2014, pp. 194196.

Agustín José MENÉNDEZ, “QQué clase de Unión es ésta? A vueltas con la saga Gauweiler", Revista Española de Derecho Constitucional, núm. 116, 2019, pp. 269-299.

Sally E. MERRY, Kevin. E. DAVIS, y Benedict KINGSBURY (eds.), The Quiet Power of Indicators. Measuring Governance, Corruption, and Rule of Law, Cambridge University Press, 2015.

Gabriel MORENO GONZÁLEZ, Estabilidad presupuestaria y constitución. Fundamentos teóricos y aplicación desde la Unión Europea, Tirant lo Blanc, Valencia, 2019.

Santiago MUÑOZ MACHADO, "Fundamentos e instrumentos jurídicos de la regulación económica", en Santiago MUNOZZ MACHADO y José ESTEVE PARDO (dirs.), Derecho de la Regulación económica. I Fundamentos e Instituciones de la regulación, Iustel, Madrid, 2009, pp. 15-243.

- "Los límites constitucionales de la libertad de empresa", en Estudios de derecho público económico: libro homenaje al prof. Dr. D. Sebastián Martín-Retortillo, Civitas, Madrid, 2003, pp. 139-164.

Joan PAGÈS I GALTÉS, "Análisis jurídico de la utilización de la estabilidad presupuestaria como límite del principio de autonomía financiera", Revista Catalana de Dret Públic (número especial), 2019, pp. 73-100.

Luciano PAREJO ALFONSO (dir.), Lecciones de Derecho Administrativo. Orden económico y sectores de referencia, 3. ${ }^{\text {a }}$ ed. revisada y actualizada, Tirant lo Blanc, Valencia, 2012.

Antonio-Martín PORRAS GÓMEZ, "La posición de la Autoridad Independiente de Responsabilidad Fiscal en el sistema constitucional de control financiero", REDC, núm. 110, 2017, pp. 143-163.

Álvaro RODRIGUEZ BEREIJO, La Constitución fiscal de España, ed. CEPC, Madrid, 2015.

- "Una perspectiva constitucional del control del gasto público", Revista Española de Control Externo, núm. 58, 2018, pp. 229-244.

Violeta RUIZ ALMENDRAL, "La reforma Constitucional a la luz de la Estabilidad presupuetaria", Cuadernos de Derecho Público, núm. 38, 2009, pp. 89-159.

Alberto RUIZ OJEDA, "Monetización del déficit público y compra de deuda soberana por el BCE/ SEBC. (A propósito de la jurisprudencia Pringle-Gauweiler-Weiss del TJUE)", Indret,3/2020, pp. 358-405.

Susana RUIZ ZARRÍAS, Las dimensiones constitucionales de la Unión Económica y Monetaria Europea, Civitas Thomson Reuters, Pamplona, 2016.

María Amparo SALVADOR ARMENDÁRIZ, "Transformaciones en la regulación bancaria: una perspectiva desde el derecho público", en José Luis COLINO MEDIAVILLA y José Carlos GONZÁ- 
LEZ VÁZQUEZ (dirs.), Las Cajas de Ahorro y la prevención y tratamiento de las crisis de las entidades de crédito, Comares, 2014, pp. 113-145.

José Eugenio SORIANO GARCÍA, "Deutschland über alles: una canción entonada por el Tribunal Constitucional alemán que invade Europa”, en LA LEY Unión Europea, núm. 82, 2020, Wolters Kluwer.

Francisco URÍA FERNÁNDEZ, "Una reflexión acerca de la constitucionalidad de las Leyes de Estabilidad Presupuestaria”, RDP, núm. 12 (2001), pp. 117-137.

— "Una sentencia oportuna e imprescindible. Comentario a la sentencia 134/2011, de 20 de julio, del Tribunal Constitucional, sobre determinados preceptos de las leyes de estabilidad presupuestaria", en Eduardo GARCÍA DE ENTERRÍA y Ricardo ALONSO GARCÍA (coords.), Administración y justicia: un análisis jurisprudencial: liber amicorum Tomás-Ramón Fernández, vol. 1, 2012, pp. 373395.

Gonzalo VILLALTA PUIG, "La constitucionalización del principio de equilibrio presupuestario: un análisis de derecho comparado", Revista las Cortes Generales, núm. 86, 2012, pp. 175-206. 
